\title{
Polypores in the parks and forests of the City of Helsinki
}

\author{
REIJO ERKKILÄ and TUOMO NIEMELÄ
}

ERKKILÄ, R. \& NIEMEL $\ddot{A}$, T. 1986: Polypores in the parks and forests of the City of Helsinki. - Karstenia 26: 1-40.

The polypores of the Helsinki municipal area in South Finland were studied with regard to their microdistributions, host relationships, abundances and economic importance. Altogether 120 species are reported. Five site types were defined, ranging from urban to rural environments: parks proper, tree rows, park forests, forests proper and idle land areas. Distinct differences were found in the species compositions of urban environments (parks proper and tree rows), as compared with more natural wooded areas (park forests and forests proper). Polypores which prefer urban growth sites (the centric species) are southern in Finland (Fistulina hepatica Schaeff.: Fr., Laetiporus sulphureus (Bull.: Fr.) Murr., Spongipellis spumeus (Sow.: Fr.) Pat.) or have a scattered general distribution (Phaeolus schweinitzii (Fr.) Pat., Polyporus squamosus Huds.: Fr., Rigidoporus populinus (Schum.: Fr.) Pouz.). Species preferring rural environments (peripheral) are mostly the basic, common forest species of southern and central Finland. A third group of polypores (indifferent) occurs evenly in all environmental types, but often varies in pathological properties between areas: for instance, Bjerkandera adusta (Willd.: Fr.) Karst., Ganoderma lipsiense (Batsch) Atk. (G. applanatum) and Fomitiporia punctata (Karst.) Murr. are more readily parasitic when growing in the inner city. The mechanisms and reasons for the fungal infections in park trees are discussed, and some commoner polypores causing rot in park trees are studied more closely. The most harmful park-tree decaying polypores in Helsinki are Ganoderma lipsiense, Bjerkandera adusta, Inonotus obliquus (Pers.: Fr.) Pil., Laetiporus sulphureus, Ochroporus igniarius (L.: Fr.) Schroet., Polyporus squamosus and Rigidoporus populinus.

The Helsinki municipal area is divided into $1-\mathrm{km}^{2}$ squares and the distributions of 30 representative species are mapped accordingly. Some typical parks, forests and polypores are illustrated.

The delimitation and species of the genus Oligoporus are discussed. The following polypores are reported as new to Finland: Oligoporus cerifluus (Berk. \& Curt.) Gilbertson \& Ryv., Polyporus badius (Pers.) Schw. and Schizopora radula (Pers.: Fr.) Hallenb. The presence of Oligoporus balsameus (Peck) Gilbertson \& Ryv. in Finland is confirmed.

Reijo Erkkilä \& Tuomo Niemelä, Department of Botany, University of Helsinki, Unioninkatu 44, SF-00170 Helsinki, Finland

Background for the study 2

Materials and methods .......................... 3

The study area $\ldots \ldots \ldots \ldots \ldots \ldots \ldots \ldots \ldots \ldots \ldots \ldots \ldots . . \ldots$

The woody vegetation $\ldots \ldots \ldots \ldots \ldots \ldots \ldots \ldots \ldots \ldots, 4$

General ........................................ 4

Classification .................................... 7

Some representative areas ..................... 8

Distribution patterns: a proposal .................... 10

List of species

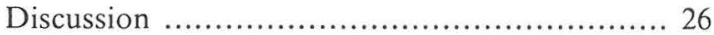

General remarks ............................ 26

Distribution patterns ............................ 27

Decay in park trees: different types .............. 35

Decay in park trees: causes and remedies ...... 35

Conclusions .................................. 37

Acknowledgements ............................ 38

References ....................................... 38 


\section{Background for the study}

The capital of Finland is situated on the southern coast of the country, at approximately $24^{\circ} 55^{\prime} \mathrm{N}$, $60^{\circ} 10^{\prime} \mathrm{E}$. The shoreline is protected from the sea by a coastal archipelago, and the downtown area is divided by numerous bays and inlets, being built on peninsulas and former islands, which are now more or less broadly connected with the main city area. The northern parts of the Helsinki area extend well inland and are not directly connected with the sea.

Helsinki falls within the eastern corner of the Hemiboreal zone in Finland (see map in Niemelä 1982), touching the transition of the Southern boreal zone. The southern floral elements are richly represented in its vegetation, but less pronounced than in the southwest, for instance in the town of Turku, or the Åland archipelago.

At present Helsinki has ca. 500000 inhabitants, and the whole metropolitan area contains roughly 760000 people. The inner city has a built-up urban structure, large parts of the centre dating back to the 18 th and 19th centuries. In contrast, the outskirts of the Helsinki municipal area comprise remnants of old countryside and numerous true forests, which have retained their original natural tree stands and lower vegetation of the kind found anywhere in the natural forests of southern coastal Finland.

A complete gradient is found between these extremes, so that Helsinki is an ideal area for studying the distributions of wood-inhabiting and other fungi along the axis of urban vs. natural habitats. Compared with the situation in Central or South Europe, the range is exceptionally wide.

So far, however, this gradient has received little attention. Lichenized fungi are those best documented in Helsinki. Vaarna (1934) studied the distributions of epiphytic lichens and found two wide lichen desert areas within the city. Since then, the quality of air has improved greatly, and later studies (Varis 1959, Nyberg 1960, Toikka 1975, Leskinen 1976) have revealed the return of many species. In the 1980s several foliose epiphytic lichens have reappeared in the very centre of the city, due to a decrease in the concentrations of $\mathrm{SO}_{2}$ (Vitikainen 1983). Local emission of atmospheric pollutants is decreasing still further; a high-risk waste disposal plant that spread heavy metals in eastern Helsinki has been closed and flue gas scrubbing units will be installed at the main coal-fired power station in the near future (1987). This new technique for controlling the purification of flue gases reduces emissions of sulphur dioxide and nitric oxides, in all by ca. $90 \%$.

Compared with the lichens, much less is known about other groups of fungi in the area. Agarics and other macrofungi in Helsinki have been investigated with regard to their contents of lead, cadmium and other heavy metals by Laaksovirta and Alakuijala
(1978), Kuusi et al. (1981) and Lodenius et al. (1981). Korhonen (1983) listed the agarics in the Botanical Garden of the University of Helsinki, and mentioned, among others, almost 20 wood-inhabiting species. His paper was included in a book edited by Jalas (1983), which also contains lists of rust fungi (Alanko 1983a), myxomycetes (Härkönen 1983) and woodrotting Aphyllophorales (Niemelä \& Erkkilä 1983) in the Botanical Garden. Only a few records have been published from the outskirts of the city. Hosiaisluoma (in Anon. 1983) compiled a list of polypores in the Mustavuori forest, on the eastern border of Helsinki. Mustavuori is the best-preserved spruce-dominated woodland within the town borders, and we shall refer to it on many occasions in the following text.

The purpose of this study is to list the polypore species in Helsinki, and to examine their distribution among environments of different types. We were especially interested in discovering whether long-established parks harbour certain characteristic polypore species. At the same time we wished to acquire information on the harm caused by fungi to different park tree species.

The work is based on the Cand.Phil. thesis of Reijo Erkkilä (Erkkilä 1984), and all the mapping was done by him. He also contributed most of the field observations and notes on the species, while Tuomo Niemelä wrote the final text and is responsible for most of the discussion. The illustrations are by Tuomo Niemelä.

Studies of this kind have surely been made elsewhere, as well, although only a few are known to us. Thesleff (1920) enumerated fungi around the town of Vyborg, at that time within Finland, but did not discuss the microdistributions of the species in the town area and its surroundings. Karlvall (1963) published a paper on larger fungi in some parks in Göteborg, Sweden. Seehann (1979) presented a thorough and detailed study on wood-destroying fungi on roadside and park trees in Hamburg, the Federal Republic of Germany. He also discussed the reasons for fungus infections on trees in urban areas, a neglected issue, although important from an economic point of view. A shorter paper deals with wood-rotting fungi in the Darmstadt Botanical Garden and its environs (Selik 1968). Nuss (1970) and Gerhard $(1978,1979)$ have prepared lists of polypores, the latter of other macrofungi as well, in parts of West Berlin. An extensive study of Benkert (1977) deals with the poroid and stereoid species of Potsdam and its surroundings in the German Democratic Republic; Dörfelt and Sommer (1973) listed the species in Halle, and Kreisel (1967) in Greifswald. Wolkinger (1973) studied wood-rotting Basidiomycetes on Aesculus hippocastanum and Sophora japonica in the town of Graz, Austria. Lawrynowicz (1982) described the macrofungal flora of the town Łódź in central Poland, and Szober 
(1965) the mycoflora in the Warsaw Botanical Garden. Selik and Aksu (1967) have made a list of more important polypores and stereoid fungi in the parks of Istanbul, Turkey. Besides these special papers devoted to town fungi, many studies on other subjects also include this kind of information and single records appear in local mycological journals.

The papers on fungi in urban areas are often restricted to enumeration of the species. Some of them discuss, at least briefly, the role of wood-rotting fungi from the economic point of view. Ławrynowicz (1982) included the inner part of Łódź in her study, and divided the municipal area into three zones: central, urban and suburban, comparing the amounts of forest symbionts, forest saprophytes, parasites, etc. in different habitats within the three zones. Though the emphasis in her study was on agarics, the questions examined by her come closest to those that we have tried to deal with in our material.

We have found that the microdistributions of the fungi in metropolitan areas have received very little attention. Perusal of extensive manuals and congress proceedings devoted to the problems of park tree management (Zion 1968, Santamour et al. 1976, Grey \& Denecke 1978, Meyer 1982, etc.) yielded only a few general references to wood-rotting fungi and even fewer to polypores. Accounts of urban and fungal ecology (e.g. Ainsworth \& Sussman 1968, Cooke 1979, Seaward 1979, Wicklow \& Carroll 1981) tend to neglect this topic, too.

In this connection we would like to mention the study of Kotiranta and Niemelä (1981), which was also based on a Cand.Phil. thesis (Kotiranta 1980). It was methodologically comparable with the present paper, but was made on natural forests in southern Central Finland. The geographical distance between these study areas is in fact small, but in character they represent the greatest possible contrast that can be found in the country - virgin forests vs. main urban centre. They may make interesting comparative reading.

\section{Materials and methods}

The field studies were made almost exclusively by Reijo Erkkilä. A great deal of the material was included in Erkkilä (1984), but collecting has been continued since then, and the period of intensive field studies now extends from 1980 to 1986. Single records, observations on earlier occurrences and additional notes on certain areas were supplied by Reima Saarenoksa, Heikki Kotiranta, Tuomo Niemelä, and others. Most of the material was gathered during summer and autumn, but scattered observations were made at virtually all times of the year.

Helsinki has been divided into $1-\mathrm{km}^{2}$ units, and this grid is used throughout the distribution maps. It ac- cords with the one used by Heikinheimo and Raatikainen (1971) and Niemelä (1982), and is based on the Finnish national uniform grid system (Grid $27^{\circ} \mathrm{E}$ ). It is presented in newer sheets of the Finnish topographical maps (1: 20000), but differs from another common grid, used in many separate town maps and in the Helsinki telephone directory (Grid $24^{\circ} \mathrm{E}$ ).

The present grid is rather coarse, and different types of environment are included in single squares, especially in the transitional areas. However, practical reasons prevented us from using a denser sampling network.

An attempt was made to obtain as complete information as possible for each square. The abundances of the species are indicated on the maps with small dots for scanty records (1-2 observations) and with large dots for 3 or more records per square.

The distribution maps are based almost entirely on material gathered specially for this study. The Botanical Museum of the University of Helsinki possesses about 600 polypore specimens deposited before 1980 , not a great number, considering that they cover a 150 -year time span. They represent mainly rare species and do not reflect true abundances. The use of old collections was often impossible because of the lack of accurate locality data; they also tend to have incomplete data on the host and other details. Further, the vegetation has changed greatly in the outskirts of Helsinki during the last few decades, and so older material would give the wrong information on the present situation. We felt it better to describe the polypore flora as it is now. In the old downtown area, the number and character of the parks have changed less, so that we could accept scattered older records as well.

Many of the fruit bodies were identified and recorded in the field, but for all critical groups or otherwise difficult species material was collected for later study. The identification and confirmation was done by Tuomo Niemelä, in most cases after microscopical examination. When the microscopy is discussed, the chemical reactions are shown in the way proposed by Niemelä (1985a, 1985b).

Specimens of rare and critical polypore species are preserved in the Botanical Museum of the University of Helsinki (H). Smaller numbers of representative specimens are likewise preserved for the commoner and (according to present knowledge) 'easy' species. Reference specimens have also been deposited in the herbaria of the authors (shortened to R.E. and T.N.) and Heikki Kotiranta (H.K.).

Basic information on the species occurring in the area can best be found in the flora of Ryvarden (1976, 1978). In the List of species, the names have been arranged alphabetically, irrespective of the systematic relationships. The genus Phellinus is divided according to the proposal of Fiasson and Niemelä (1984). 
The name Spongiporus (David 1980) has been retained instead of Postia, until the typification of the latter is settled.

In the section List of species, different ways of expressing the occurrences were adopted, depending on the abundance of the species. For the rarest, unmapped species the coordinates of the finds are given. For somewhat more numerous species, the numbers of finds on each host are given. For common species, (having finds well over 10) the squares with finds on a certain host are given as percentages of all the recorded squares, i.e., if several records on a certain host derive from a single square, they are counted as one. This method underemphasizes the importance of the main host trees, especially if the polypore species tends to occur in abundant but restricted populations. However, it was impossible to count every single polypore individual of common species in this study, which was mainly devoted to the general distribution.

Maps of all the species are preserved in the Library of the Department of Botany, University of Helsinki (Erkkilä 1986).

Every entry in the List of species consists of information on the occurrence, supplemented with notes on the distribution type, economic importance, etc. The words referring to the abundances are approximate only and based on subjective estimates of the authors.

The nomenclature of the host trees follows HämetAhti et al. (1984) for indigenous species. The following common names are used: pine (meaning Pinus sylvestris), spruce (Picea abies), alder (Alnus glutinosa and $A$. incana), aspen (Populus tremula) and birch (Betula pendula and B. pubescens). The names of the exotic tree species have been taken from Flora Europaea (Tutin et al. 1964 and later volumes).

\section{The study area}

The study area is illustrated in Fig. 1 and comprises the whole of mainland Helsinki plus most of the adjacent islands. Access to some islands was limited by dense settlement, private gardens, or use by the defence forces, and they have been less completely studied than the mainland. The major practically unstudied islands are Isosaari (outside the map), Kuninkaansaari, Melkki, Santahamina and Vallisaari. Suomenlinna and Pihlajasaari, on the other hand, were rather well examined. The eastern parts of mainland Helsinki, close to the border of Vantaa, have generally been better studied than the northwestern corner. The city itself was also very well examined.

Fig. 1 gives some general features of the study area. Especially important are the downtown area, which comprises the oldest and most densely built-up part, and the forested outer areas, which represent the other extreme. Between these, very large areas are covered with lighter, more widely spaced buildings, for instance suburbs and districts with light industry. They vary greatly in their plant cover, containing cleared land and young parks, but of ten also parts of older forests. Their wooded areas are undergoing the most rapid changes.

The map gives the names of some important localities appearing in the text. In two cases we have included minor areas outside the borders of Helsinki. The whole Mustavuori forest area is included, although it is dissected by the border of Vantaa. The other area is the protected Tammisto forest in the north. Both forests have exceptionally rich polypore floras.

\section{The woody vegetation}

\section{General}

The total land area of Helsinki is ca. $185 \mathrm{~km}^{2}$. About 900 ha of it is covered with parks proper, and about 3500 ha with different kinds of woodland. Abundant trees and bushes occur in private gardens, empty lots, etc. and these were also included in our study.

Many parks have been created gradually, and exact dates for their establishment can seldom be given. The oldest parks of the downtown area assumed their present character about 150 years ago. For instance, the University Botanical Garden (Jalas 1983) and the Kaisaniemi park (Alanko 1983b) were established in the 1830s. Another remarkable old park, Kaivopuisto, was created at the same time, but the peak of its development dates to 1840-1890 (Uotila et al. 1981).

Most old parks have evolved little by little from earlier forests. In 1976-1977 a general park management scheme was introduced. As a result, landscaping has become commoner, and many recent parks have been created on former barren areas. Such landscaping includes the covering of the terrain with topsoil and the planting of trees according to a certain design. Therefore, compared with those of old parks, the tree stands of newer parks differ more in species composition from natural Finnish forests.

Because of the great amount of exotic species in the parks, it can safely be said that Helsinki harbours more tree and shrub species than any other corresponding area in Finland. This and the high average age of the plantations result in a rich flora of woodinhabiting fungi.

In eastern Helsinki, the Viikki arboretum, covering 20 ha, contains over 300 tree species (Anon. 1986b). Established in 1969, it is still too young to contribute to the present study.

About 100000 trees and bushes are planted annually in Helsinki, including ca. 11000 coniferous trees and 5200 deciduous trees (1984). Different trends and practices in the management are reflected in the 


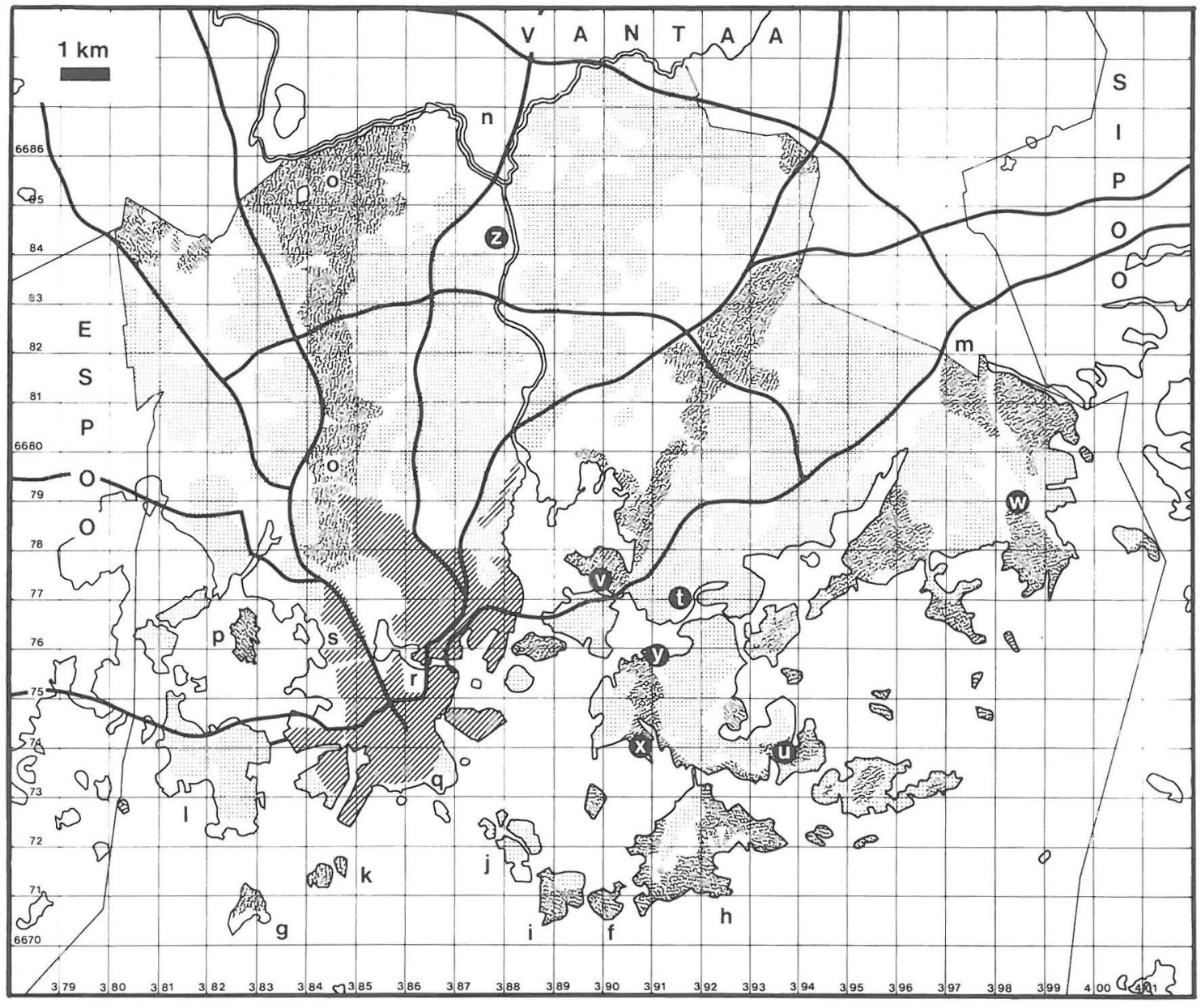

a

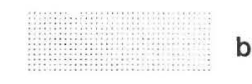

b

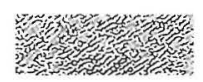

$\mathrm{c}$
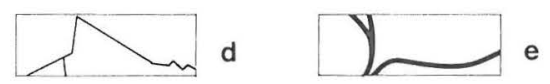

Fig. 1. The Helsinki municipal area, ca. 1: 150000 . The figure shows the mapping grid and its coordinates, and some details referred to in the text. - a) The densely built-up inner city, b) less densely built-up areas (residential sections, suburbs, light industry), c) main forest areas, d) municipal boundaries, e) main freeways and connecting viaducts, f) Kuninkaansaari, g) Melkki, h) Santahamina, i) Vallisaari, j) Suomenlinna, k) Pihlajasaari, 1) Lauttasaari, m) the Mustavuori forest, n) the Tammisto nature reserve, o) Keskuspuisto, p) Seurasaari, q) Kaivopuisto, r) Kaisaniemi, s) Sibeliuspuisto. Manors: t) Herttoniemi, u) Jollas, v) Kulosaari, w) Nordsjö, x) Stansvik, y) Tullisaari, z) Tuomarinkylä.

amounts of various tree species planted during different periods. Tilia $\times$ vulgaris has retained its popularity because of its hardiness, tolerance of pruning, and longevity. However, during recent decades, more diversity has been achieved by planting certain boulevards with special trees, for example Acer platanoides, Aesculus hippocastanum, Sorbus aucuparia, $S$. intermedia and Junglans ailantifolia.

The trees most commonly planted during the 1980s have been, in descending order of popularity, Tilia $X$ vulgaris, Betula pendula and Sorbus aucuparia. The problematic Betula, however, is now steeply decreasing. The noble rows of Salix alba in the city centre date from a short period 60-80 years ago, and no extensive newer plantations have been made. The popularity of Fraxinus excelsior, too, has decreased, most present individuals being 40 years old. Poplars (Populus, especially sect. Tacamahaca) have also lost their former position because of their short life span, unpleasant litter production, and too robust growth, 

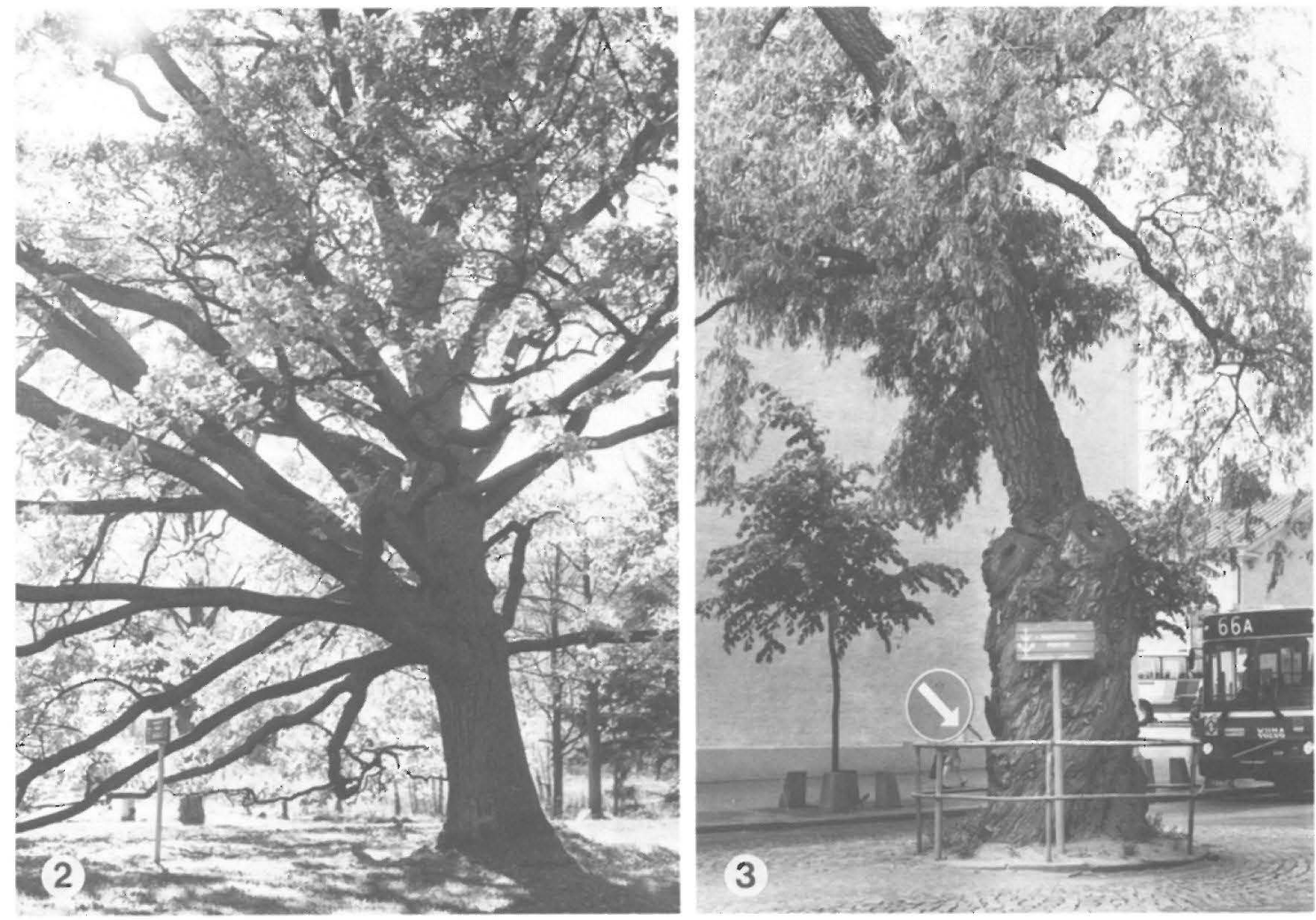

Figs. 2-3. Protected trees in Helsinki. - 2: An old, healthy Quercus robur in Tullisaari (6675:390). -3 : Salix $\times$ rubens, infested by Ochroporus igniarius, in the city centre (6674:385).

which necessitates frequent pruning. Quercus robur and Ulmus glabra, on the other hand, have witnessed a renaissance during recent years, though the latter seems to thrive in good sites only. Promising newcomers are the trunk-forming species and varieties of Malus, and some hardy Juglans species.

The cultivation of conifers in the centre was almost nil from the end of the 19th century till the 1950s, because of the polluted air. Since then plantations have been more successful and old remaining conifer individuals have been recovering. With the advent of long-distance pollution the situation is again deteriorating, and some old spruce and pine forests show signs of degeneration. The planting of Pinus sylvestris has increased greatly during the 1980 s, e.g. along the exit freeways. Recent plantings with Larix sibirica have been successful, and a revival is expected for this beautiful conifer. Exotic Pinus mugo is popular along roadside slopes.

There are several officially protected areas in Helsinki. Some of them comprise small islands of the outer archipelago (e.g. Nuottakari, 1.5 ha, and Matalahara, 4 ha). They have been protected mainly as nesting areas for sea-birds, but as a result their vege- tation remains in a natural state. Some of the inner islands (e.g. Tiirakari, $2.2 \mathrm{ha}$, adjacent to Lauttasaari) are protected, too. In mainland Helsinki the most extensive protected area is the Viikki Nature Reserve (ca. 250 ha, 6679:388-389 and surroundings), which consists of reeds and other wetlands, internationally renowned as a bird-nesting area, and also of coastal alder woods. The Kallvik peninsula (6676:396-397, 6677:396-397) includes a protected ridge of pine forest ( 6 ha) and a sandy coastal strip, covered with old pine woodland. On 5 June 1986, the City Council made a decision to protect 35 ha of the Mustavuori forest (Fig. 1:m), which will be described later.

In northern Helsinki, some important nature reserves are located adjacent to the Keskuspuisto forest (Fig, 1:0) along the Vantaa border. The Niskala arboretum (2.25 ha) was established in 1905-1917 and contains ca. 20 species of exotic conifers and over 30 deciduous tree species. The Haltiavuori virgin forest (22 ha) is a dense, spruce-dominated forest of a rich Oxalis-Myrtillus site type; it was only recently accorded complete protection and the woody vegetation has not yet reached the climax stage. Noteworthy is also the protected slope at Pitkäkoski bearing grass- 
herb forest and climax-stage spruce stands (6686:384, 12.6 ha). It lies along the border of Helsinki and Vantaa, on the Vantaa side. Close by it (in Vantaa) is the Tammisto nature reserve, which is made up of old oak stands and is included in our study and distribution maps (Fig. 1:n).

In Helsinki there are about 25 protected tree individuals or groups of trees, some of them are situated in the inner city parks or streets. They include 8 individuals of Pinus sylvestris, 4 of Quercus robur, 3 of Betula species, 2 of Picea abies 'Virgata', Salix $X$ rubens and Tilia species, and single individuals of $\mathrm{Ul}$ mus glabra, Salix fragilis, Populus alba and Juglans species. Most of them receive special treatment and care during their growing seasons, fertilizers and regular high-pressure watering.

\section{Classification}

We here propose a rough classification of the tree stand types, or environment types for the wood-rotting fungi, which will be used repeatedly in the following discussions. The definition of the types is not always easy or possible in the field, but we hope that this classification will help to clarify the ecological differences between the sites.

I Parks proper. This type consists of wooded areas specially designated and landscaped as parks. The ground has been at least partially covered with additional topsoil, to shape it more gently and make it more suitable for lawns. The grass is mostly cut regularly and the fertility and $\mathrm{pH}$ of the soil are controlled. The park is planted with trees obtained from nurseries, though a few original old trees may remain here and there. Cultivars are common. The species composition is exotic-dominated and very unlike that of the natural forests which existed at the site. The trees are allowed to grow old and receive individual care.

The tree stand of type I is best represented in the inner city, but younger examples of this site type are found in the outskirts, too. Centres of old residential areas (e.g. Lauttasaari) contain outliers of this type. The parks of old manor-houses should also be classified as parks proper, having a similar history, dendrological composition and tree age structure, although they are scattered all over the study area, thus obscuring the distribution patterns. The most notable are the parks of the Herttoniemi, Jollas, Kulosaari, Nordsjö, Stansvik, Tullisaari and Tuomarinkylä manors (see Fig. 1:t-z).

II Tree rows. This stand type embraces alleys, boulevards and other sites in which the trees are planted along sidewalks, highways or buildings. Single trees planted in small plots of ground in parking lots, etc. are also included. The ground is surfaced with asphalt or other material, or exposed soil is res- tricted to a narrow strip of lawn. This interferes with the aeration and water balance of the roots. Further, the soil is often of poor quality: compacted and polluted with de-icing salts and other toxic spills. The roots are stunted because the trees are relatively big when planted and ditches are often dug beside them to lay or service the water-, gas- and electricity mains. The trees are heavily pruned to make their shape more upright; this results in numerous large scars which serve as passages for infecting fungi. The trunks are subject to damage by traffic and snow ploughs, and butt bark injuries are common. All in all, the trees of this class are exposed to the greatest environmental stresses. Both indigenous and exotic species are found, but the range of species is small.

Trees belonging to this class are found in all builtup areas, but the most characteristic situations exist in the old centre. Very common are also sites which can be classified as intermediates between types I and II.

III Park forests. The tree stands of type III originate from natural forests or natural saplings, but their management has changed, mainly because they have been engulfed by new suburban areas. The trees have normal root systems because of their natural origin and they represent original provenances. The ecology of these 'cleaned' forests, however, has been disturbed in many ways. The stands are less dense than in nature. The undergrowth has often been cleared, and the grass and superficial roots of, for instance, spruce, suffer from trampling. Changes in the water table are common, due to adjacent building. The disturbed ecology is often reflected in a weakened condition of the trees, especially the conifers. Stumps are mainly left to decay, but other woody debris is uncommon. The trees of the park forests seldom receive individual care; they are generally removed if they do not thrive, and replaced with new plantations. The soil is often supplemented and improved in this connection, and the tree species altered, and so park forests are changing slowly into site type I.

This site type is commonest in and around the newer subdivisions, but is also found closer to the centre. For instance, parts of the Sibelius park, composed of birches, mainly represent the park forest type.

IV Forests proper. This is the most natural type of tree stand. The trees belong to original provenances, and the vegetation in the bush, field and ground layers is in a fairly natural state. The stress of trampling is present, but mostly channelled to paths. The tree stands of type IV are often conifer-dominated, such as moist spruce-mixed forests or dry pine stands on rock outcrops. Deciduous grass-herb forests are rarer. Stumps and woody debris are abundant and fallen trunks are also found.

True forests are commoner in the outskirts, close to 
the town borders, and many of them are at least partially protected for recreational purposes. The Keskuspuisto greenbelt largely belongs to this type, as does also the woodland of the Seurasaari open-air museum. Mustavuori is a good example.

V Idle land areas. These are mostly small areas, cleared from trees but supporting dense stands of bushes and saplings, for instance, empty lots awaiting future building or other land use. Remnants of former gardens which have been left to run wild (e.g. because of changes in land use) are comparable with idle land areas, and support a rich mycoflora because of abundant unmanaged Acer platanoides, Malus $\times$ domestica, Prunus domestica, P. insititia, Syringa vulgaris, etc. Brooksides and waterlogged areas also belong here. Environments in this class are often enriched, having a ruderal character. Dead woody debris may be abundant. Ecologically very variable, these are often good growth sites for smaller ephemeral polypore species.

Besides occurring in the site types described above, polypores sometimes emerge in more exceptional circumstances, e.g. on the wood of greenhouses, saunas or other structures. They fall outside the scope of this study, and are mentioned only casually in the list of species.

\section{Some representative areas}

The Kaivopuisto park (Fig. 4) covers 16 ha, to which may be added some adjacent parks and park-like sections. About 130 woody species and cultivars are known to occur in the park (Alanko 1981). Most of its present trees were planted at the end of last century, but several pines, birches, alders, chokecherry and rowan trees reflect the original forests of the area. A major replanting program was carried out during 1946-1957. The whole area now represents site type I. The most numerous trees, in descending order, are Acer platanoides, Tilia $\times$ vulgaris, Alnus glutinosa, Ulmus glabra and Betula pendula. A complete list is presented, and the commonest are described and illustrated in Uotila et al. (1981).

The park of Kaisaniemi (Fig. 5) and the University Botanical Garden make up a single unit, divided only administratively. Together they equal Kaivopuisto in size. Kaisaniemi contains ca. 30 tree species and 50 bushes (Alanko 1983b). The commonest tree is again Acer platanoides, followed by Betula pendula; almost all the birches are found along a single alley. The section of the Botanical Garden is much richer in trees; 600-700 woody species, subspecies, varieties or cultivars have been recorded there (Alanko 1983c, Palmén 1985), but the number includes woody vines, small bushes, etc., which have little interest in our study. The diversity of the trees does not allow any species to be distinctly dominant, but the large stands of Larix, Acer, Populus and Ulmus are of special interest to us. The garden possesses an old Ulmus laevis over $30 \mathrm{~m}$ tall, claimed to be the biggest individual of the species in Fennoscandia and evidently dating back to the time before the park was created. One Larix sibirica has reached 200 years of age and two others 150 years (Palmén 1985). The whole area represents site type I.

The Sibelius park (Fig. 8) represents a younger generation of parks. The park-like management developed gradually, but the core emerged as a park in the 1940s. In all, 40 tree species are found (Alanko, pers. comm.), but the tree stand in the main central area consists almost exclusively of birches, Betula pendula and (less often) $B$. pubescens. The trees have grown from natural saplings, and so the park represents site type III.

The Keskuspuisto (Fig. 9) is an extensive wedge of forested land, extending from the city centre to its northern border. Totalling $600 \mathrm{ha}$, it is the main recreational area of Helsinki, and a unique greenbelt in a city of this size. Its southern parts consist of parkland, but it is mainly close to site type IV; the northern part (called Haltiavuori) comprises 300 ha of uninterrupted forest (Anon. 1979). The tree stands give the impression of genuine forest, but dead trees and woody debris have mostly been removed, and so the conditions are not optimal for saprophytic fungi. In the Haltiavuori area, however, there is a virgin forest of 22 ha, which has been in a completely natural state for over 40 years (Anon. 1979). The vegetation varies greatly in the different areas, the commonest trees being Picea abies, Pinus sylvestris (in drier sites), Betula species, Sorbus aucuparia and Populus tremula.

The Mustavuori forest (Figs. 6-7), comprising ca. 90 ha, is a fairly natural wooded area, ranging from dry pine hills to rich spruce forests and including some of the best remaining grass-herb forests on the southern coast of Finland. The vegetation has been described thoroughly by Väinö Hosiaisluoma (Anon. 1983). Very common trees are Picea abies, Pinus sylvestris and Betula pendula. Commonly found are $B$. pubescens, Alnus incana, A. glutinosa, Populus tremula, Salix caprea and Prunus padus. Rare or scattered species are Tilia cordata, Acer platanoides and Quercus robur. Of the bushes, the most important for our study is the abundant Corylus avellana. This valuable area belongs to site type IV.

Figs. 4-5. Old, established parks in Helsinki. - 4: The Kaivopuisto park harbours a rich variety of centric polypores. - 5: The rows of Salix alba in Kaisaniemi suffer from Laetiporus sulphureus. 

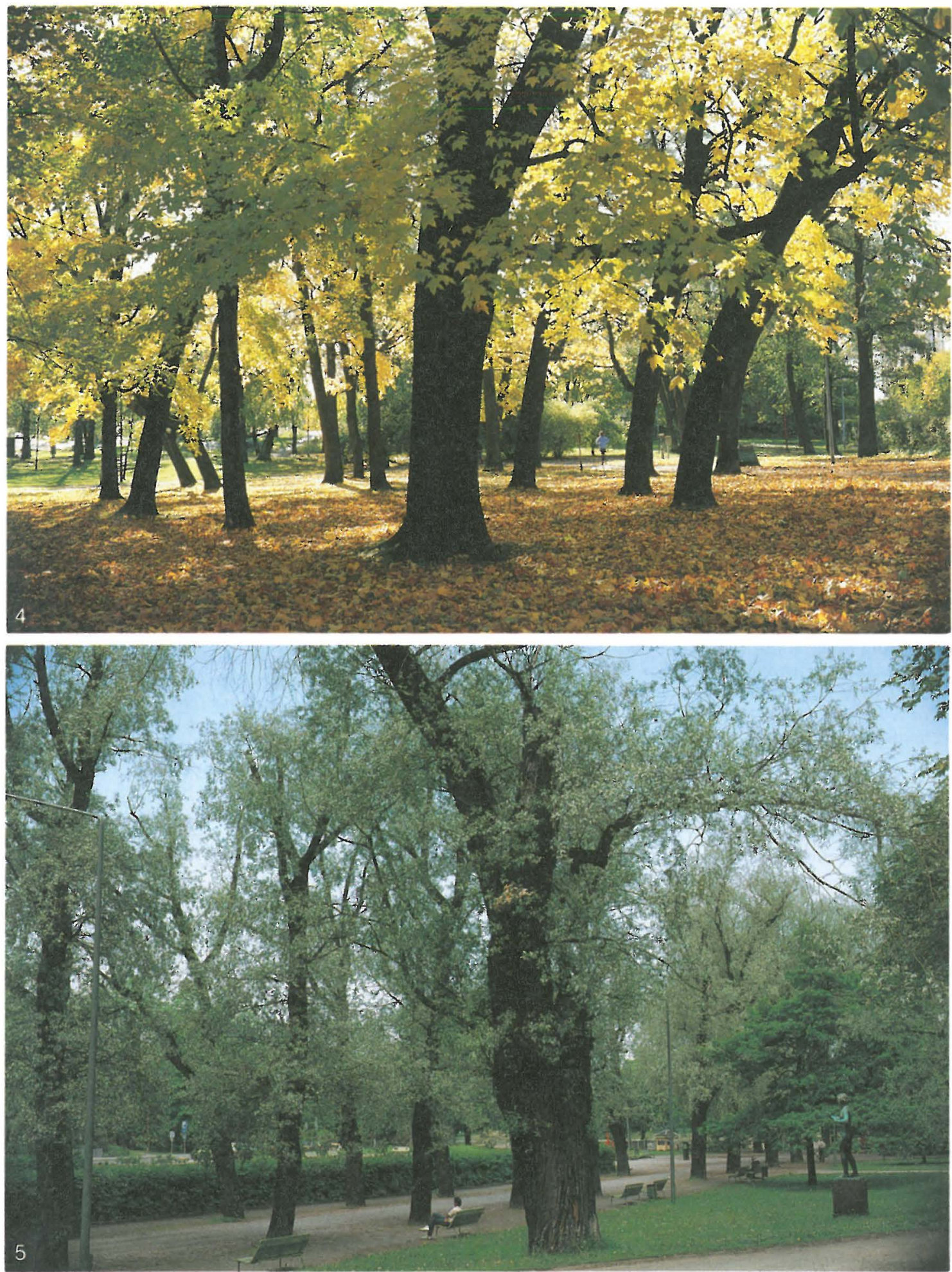


\section{Distribution patterns: a proposal}

Our main interest was to study the preferences of the polypore species for various tree stand types. For that purpose three distributional patterns are outlined. The division is tentative, and will be discussed more thoroughly when the observations of each species can be summarized. The proposed distributional patterns are:

A Centric. This is shown by the polypore species which have a more or less clear preference for tree stand types I and II (parks proper and tree rows). This means that they occur more readily in the builtup areas than in the peripheral, more natural environments.

B Peripheral. This distributional pattern is evident in the species which are common in tree stand types III and IV (park forests and forests proper), perhaps also $\mathrm{V}$ (idle land areas), but are distinctly rarer near the town centre or do not occur there at all.

C Indifferent. Polypores with indifferent distribution can be found in all five stand types, though their abundances need not be exactly the same in all the types. Their ecological and pathological properties may vary according to the environmental type, for instance their tendency to parasitic growth habit.

In deciding the distributional pattern of a certain species, we sometimes used supplementary information from other South Finnish towns. This was especially necessary for the rare species. The distribution maps will be grouped according to the above division. For a more comprehensive analysis, see the section Discussion.

\section{List of species}

Albatrellus confluens (Alb. \& Schw.: Fr.) Kotl. \& Pouz.

Three records from spruce forests in the eastern outskirts of Helsinki. The abundance varies greatly in different years and the true occurrence is difficult to estimate.

A. ovinus (Schaeff.: Fr.) Kotl. \& Pouz.

Uncommon in spruce forests in the outskirts. Abundance varying with the year.

A. subrubescens (Murr.) Pouz.

One record (6676:397) from pine heath. The occurrence of this species in Finland has remained obscure, although Pouzar (1974) established that it belonged to the Finnish polypore flora. The whitish Albatrellus species are mostly collected for food and are underrepresented in herbaria. However, there are now several verified finds of this species in southern Finland, all from pine forests. Ryman and Holmåsen (1984) discussed its distribution in the Nordic countries and published a coloured plate.

\section{A. syringae (Parm.) Pouz.}

One record (6680:385), on a lawn in a residential neighbourhood. The species is known in Finland from 19 localities, all over the country. The first finds were published by Niemelä (1970). All the sites are under strong human influence: cemetery and other lawns, fills and other disturbed soils, or lightly pastured woodlands. The general distribution of $A$. syringae is concentrated around the Baltic countries: Sweden, Finland and the Estonian S.S.R. A single collection derives from the Austrian Tyrol, at an altitude of 1100 metres (Malençon 1966, as Polyporus peckianus, teste Niemelä).

Amyloporia xantha (Fr.: Fr.) Bond. \& Sing. Pinus sylvestris (5 finds), Picea abies (1), Salix caprea (1). Uncommon, and mostly found growing on wooden structures and on stumps.

Antrodia heteromorpha (Fr.: Fr.) Donk

Picea abies (1 find). Very rare: a single collection from the year 1957 (exact locality unknown, HFR), stump of spruce.

\section{A. macra (Sommerf.) Niemelä}

Salix caprea (9 finds), Populus tremula (1). Earlier known as Antrodia salicina (Niemelä 1978a, 1985), this species has been collected many times in some eastern Helsinki grass-herb forests and thickets. It favours site types IV (forests) and V (idle land), demanding a shady, undisturbed bush vegetation. Some of its best growth sites (6678:386 and 6681:391) in Helsinki are being occupied by expanding university campuses.

A. pulvinascens (Pil.) Niemelä

Populus tremula (3 finds). A very rare species, found in the forests of eastern Helsinki. Earlier Finnish finds of this species (as $A$. plicata) were published by Niemelä (1978a) and Kotiranta and Niemelä (1981). The Fennoscandian distribution was mapped and the name change discussed by Niemelä (1985a).

A. serialis (Fr.) Donk

Picea abies (90\%), Pinus sylvestris (7\%), single records from Betula, Larix, Populus tremula and Prunus padus, and several collections from unidentified building wood. Common in natural environments, but very rare in the inner city and there only on wood in buildings. Most often on stumps in forests and forest clearings; also on fallen, decorticated trunks of spruce. Unexpectedly few records derive from pine. 

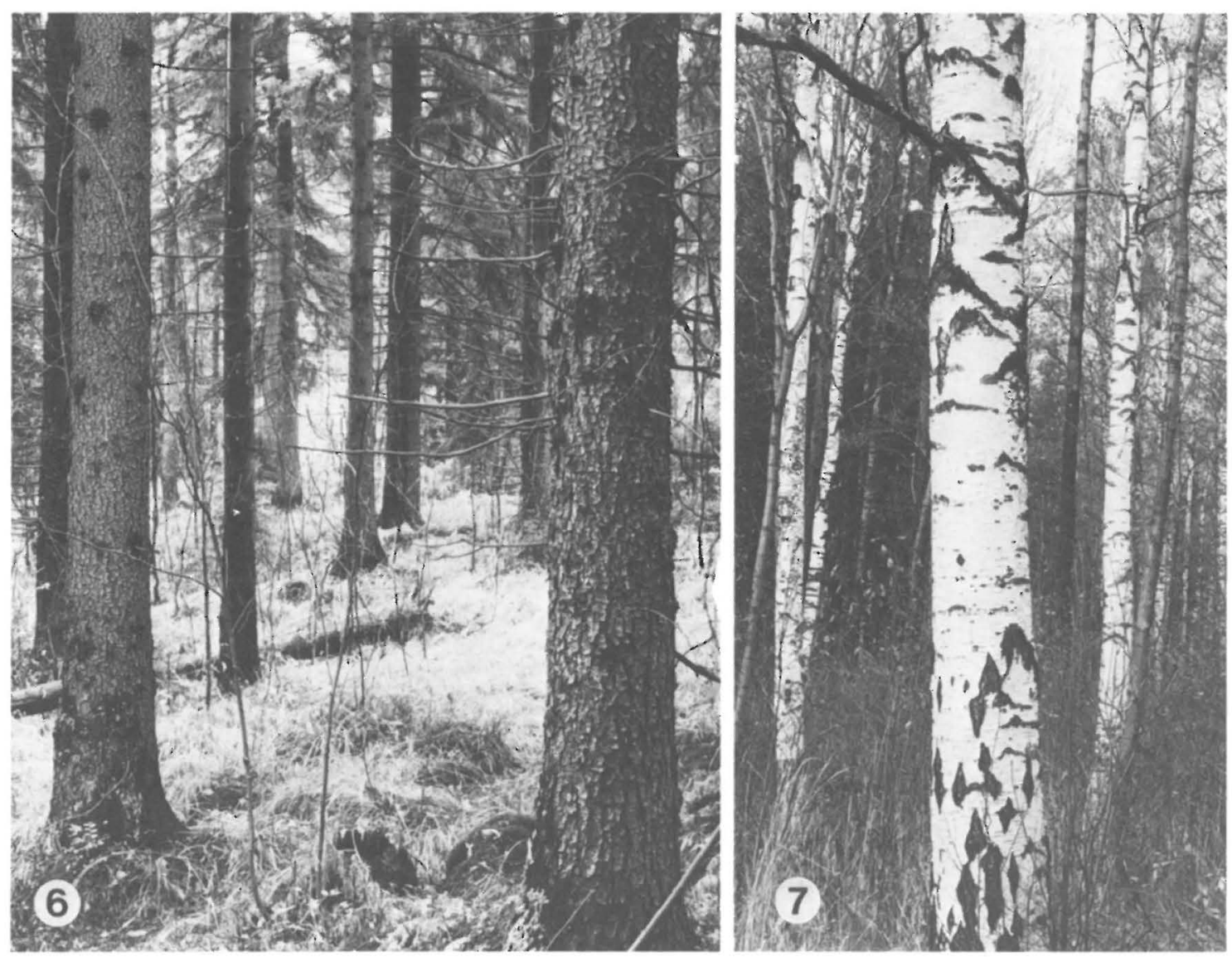

Figs. 6-7. Mustavuori, a representative natural forest area. - 6: Rich spruce forest. - 7: Birch-dominated grass-herb forest, with Acer platanoides, Populus tremula and Corylus avellana.

A. sinuosa (Fr.) Karst.

Picea abies (67\%), Pinus sylvestris $(25 \%)$, single records on Betula and Prunus padus. The peripheral distribution and occurrence on dry wood make the species resemble Amyloporia xantha. Both are surprisingly rare in the study area, although they are generally common or very common in Finland, and a special look-out was kept for them.

\section{Antrodiella hoehnelii (Bres.) Niemelä}

Corylus avellana (4 finds), Betula (3), Salix caprea (3), single records on Alnus glutinosa, A. incana, Quercus robur and Sorbus aucuparia. The species is peripheral, and generally uncommon. In some areas, however, it has agglomerated occurrences, and it is found fairly regularly in, e.g., the forests of Haltiala and Mustavuori. A. hoehnelii grows almost solely on dead fruit bodies of Inonotus radiatus, but is far more restricted in its distribution than the latter species. No record exists of $I$. radiatus on Quercus robur.
A. onychoides (Egel.) Niemelä

Prunus padus (3 finds), Acer platanoides (1), ?Alnus incana (1), Betula (1), Quercus robur (1). A very rare, peripheral polypore, found but a few times in shady grass-herb forests. First reported from Finland by Niemelä (1981), the species has now been found in some localities along the southern coast. This neglected polypore has been shown to be widespread in Central and South Europe (Bernicchia \& Furia 1982, Grosse-Brauckmann \& Jahn 1983, Grosse-Brauckmann \& Grosse-Brauckmann 1983 and GrosseBrauckmann 1985).

\section{A. romellii (Donk) Niemelä}

Sorbus aucuparia (6681:397). A rare species growing on hardwood litter.

A. semisupina (Berk. \& Curt.) Ryv.

Betula (5 finds), Salix caprea (3), Alnus glutinosa (1), Corylus avellana (1), Prunus padus (1) and Sorbus aucuparia (1). A rare, peripheral species, although its 


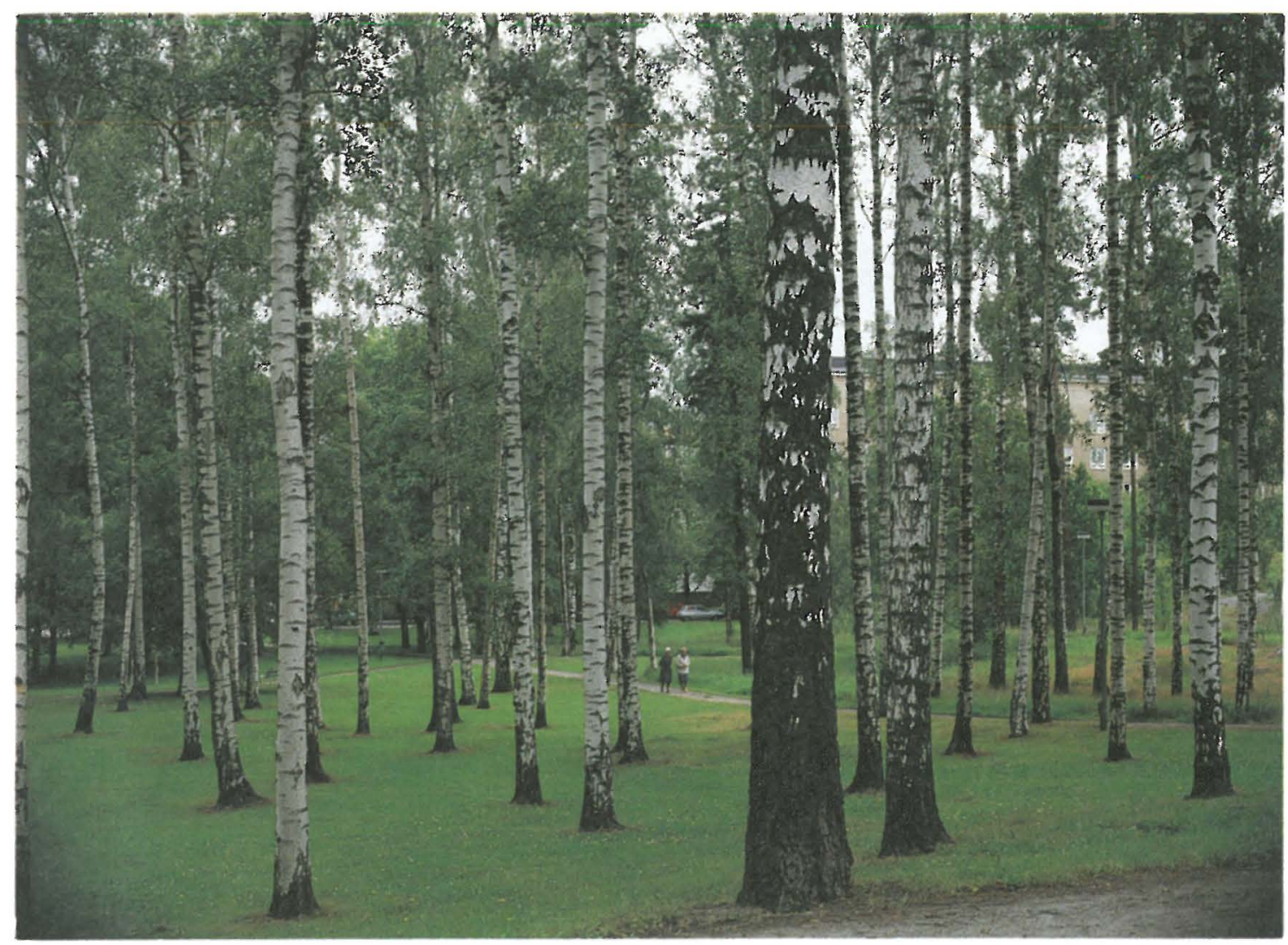

Fig. 8. The Sibelius park, representing site type III (park forest). The birches originate from a natural stand, but the area is now managed as a park. It harbours rather a few polypore species.

host (dead Fomes fomentarius) is widespread and common in the area. No record exists of $F$. fomentarius on Prunus padus.

Aporpium caryae (Schw.) Teix. \& Rogers Pinus sylvestris (6679:387), processed wood.

Aurantioporus fissilis (Berk. \& Curt.) Jahn Betula (6679:387). The fruit body was found by Heikki Kotiranta in a cavity in a hollow log. Earlier Finnish finds were listed by Niemelä (1978b).

Bjerkandera adusta (Willd.: Fr.) Karst. Betula (47\%), Picea abies (24\%), Sorbus aucuparia $(7 \%)$, Acer platanoides (5\%), Alnus glutinosa (5\%), Populus tremula (5\%), single records on Acer negundo, Aesculus hippocastanum, Corylus avellana, Fraxinus excelsior, Malus baccata, Pinus sylvestris, Prunus padus, Quercus robur, Robinia, Salix alba, S. caprea, Sambucus racemosa, Tilia $\times$ vulgaris and Ulmus glabra. One of the most characteristic of the polypores having an indifferent type of distribution. $B$. adusta is a widespread polyphagous species, commonly found on birch stumps. In peripheral areas it was observed surprisingly often on stumps of spruce. As a rule these belonged to trees that had fallen or been felled rather recently, but the species is definitely a saprophyte in the peripheral areas. In the inner city, on the other hand, many finds were made on large scars of living deciduous trees, and in such cases the fruit bodies form abundant, large, imbricate covers. This is a harmful parasite of injured deciduous park trees. - Fig. 47 (map).

\section{B. fumosa (Pers.: Fr.) Karst.}

Acer platanoides (2 finds), Salix caprea (2), Salix sp. (2), single records from Acer negundo, Alnus glutinosa, Betula, Fraxinus excelsior, Malus baccata, Populus, Sambucus, Ulmus glabra. B. fumosa has a more centric tendency than appears in the map. Almost all finds derive from old parks, for instance the vicinity of manor-houses. It is initially a weak parasite, but fruits abundantly only in extensively decayed stump remnants. A great proportion of the finds were made 


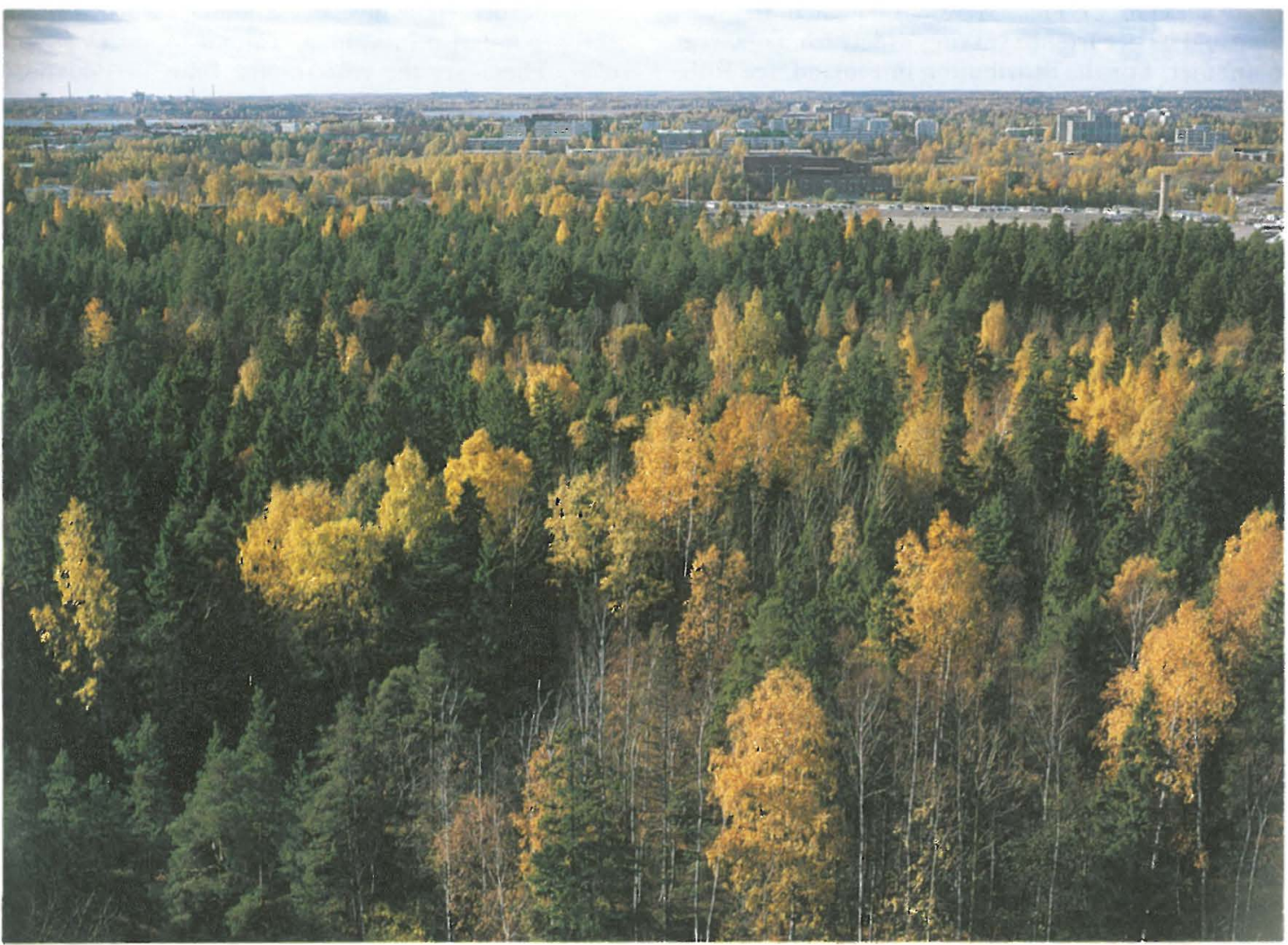

Fig. 9. The Keskuspuisto green belt, photographed in grid square 6679:384 facing southwest. Dominant spruces and birches are intermixed with scattered pines and aspens.

on exotic hosts. These features of the ecology have been observed elsewhere in southern Finland as well. - Fig. 53 (map).

Ceriporia purpurea (Fr.) Donk

Two records $(6677: 390,6680: 390)$ from eastern Helsirki, from a cavity in a weak old Acer platanoides, and from Populus tremula.

\section{C. reticulata (Hoffm.: Fr.) Dom.}

Alnus incana (2 finds), Corylus avellana (2), Prunus padus (3), Salix caprea (5), Sorbus aucuparia (2). Found in four localities (6680:389, 6681:390, 6681:397, 6682:391).

\section{C. viridans (Berk. \& Br.) Donk}

Acer platanoides (1 find), Betula (1), Salix caprea (3). Old records from eastern peripheral areas (HFR), and recently found by Reima Saarenoksa (6681:397, 6682:391).

Ceriporiopsis resinascens (Rom.) Dom.
Populus tremula (6 finds), Salix caprea (4), Salix sp. (1). Scattered finds in the transitional areas between the inner city and the peripheral forests, favouring site type $\mathrm{V}$.

Cerrena unicolor (Bull.: Fr.) Murr.

Betula (54\%), Acer platanoides (12\%), Populus tremula $(11 \%)$, Salix caprea $(8 \%)$, Alnus incana $(7 \%)$, Sorbus aucuparia (4\%), Alnus glutinosa (3\%), single records from Acer sp., Populus sp., Quercus robur, Salix sp., Ulmus glabra. A common species with a peripheral preference. C. unicolor is mostly saprophytic, being found on stumps, fallen trunks and woody debris in forest clearings. It was collected a few times on living trees. It resembles Lenzites betulina in its preference for birch, and has similar growth sites. It also has a resemblance to Pycnoporus cinnabarinus in being frequent in dry forests on rock outcrops. Although peripheral, it favours a slight human influence.

Climacocystis borealis (Fr.) Kotl. \& Pouz. 
Picea abies (96\%), Pinus sylvestris (single find). Scattered and its occurrence varying widely from one year to another. For the distribution in Finland, see Kotiranta and Niemelä (1981).

Coltricia perennis (L.: Fr.) Murr.

On sandy soils, scattered and rather uncommon.

Daedalea quercina L.: Fr.

Quercus robur (6673:390, 6674:390, 6686:378). One collection derives from an extensively decayed stump, two others from joints of dead branches in living trees, relatively high above the ground. These are the easternmost localities of the species in Finland, and no earlier records exist from Helsinki. Although the finds are not from the inner city, D. quercina should be considered centric in its ecology: characteristic growth sites are old parks.

Daedaleopsis confragosa (Bolt.: Fr.) Schroet.

Salix caprea $(77 \%)$, Acer platanoides $(15 \%)$, Sorbus aucuparia ( $8 \%$ ), single records on Alnus glutinosa and Populus tremula. Generally rare in the area, but in some sites locally abundant on numerous adjacent, thin willow trunks. If the number of finds on $S$. caprea were given (instead of the proportion of squares), its preference for this host would be even more evident. Once established, the species can occupy new close-by host trees, but the patchy distribution gives the impression that the long-distance dispersal by spores is rather inefficient. This feature makes it vulnerable to environmental changes. $D$. confragosa is best represented in site type $\mathrm{V}$.

\section{Datronia mollis (Somm.) Donk}

Populus tremula (19\%), Prunus padus (19\%), Salix caprea (19\%), Betula (11\%), Sorbus aucuparia (11\%), Alnus incana (9\%), single records on Acer platanoides, Alnus glutinosa, Fraxinus excelsior and Salix sp. A scattered species, and often hard to find because of its growth on thin, fallen twigs. It is a characteristic inhabitant of bushy idle land areas (site type V) and slightly peripheral.

Diplomitoporus lindbladii (Berk.) Gilbertson \& Ryv. Corylus avellana (1 find), Picea abies (1), Pinus sylvestris (1), Salix caprea (1). A rare species, collected in Helsinki in three localities (6679:387, 6680:389, 6682:397).

Fibuloporia mucida (Pers.: Fr.) Niemelä

Picea abies (5 finds), Alnus glutinosa (1), Betula (1), unidentified frondose wood (1). A rare species, peripheral.

Fistulina hepatica Schaeff.: Fr.

Castanea sativa (6675:386). Known in Helsinki from a single locality, the University Botanical Garden. Recently found also in Vantaa: Tammisto, on Quercus robur. These are the easternmost finds in Finland, discussed by Niemelä \& Erkkilä (1983) and Niemelä \& Kotiranta (1986). We regard this species as centric on the basis of supplementary records from southern and southwestern Finland. - Figs. 10, 29 (map).

Fomes fomentarius (L.: Fr.) Fr.

Betula (88\%), Populus tremula (5\%), Alnus glutinosa (4\%), Sorbus aucuparia ( $1 \%$ ), single records from Acer platanoides, Alnus sp., Corylus avellana, Quercus robur, Salix caprea and Tilia sp. Found only a few times in the inner city (site types I and II), fairly common on idle land (V) and in park forests (III), and very common in the forests proper (IV). This peripheral species is a harmful pathogen of birch, chiefly causing problems in recreational areas, where trees are kept longer than in most managed forests. - Fig. 35 (map).

Fomitiporia punctata (Karst.) Murr.

Salix caprea (53\%), Prunus padus (14\%), Sorbus aucuparia (13\%), Betula (4\%), Corylus avellana (4\%), Populus tremula (3\%), single records on Acer ginnala, A. platanoides, Alnus glutinosa, A. incana, Crataegus oxyacantha, Lonicera xylosteum, Malus sp., Salix myrsinifolia, Sambucus racemosa, Sorbus intermedia, Syringa vulgaris and Viburnum opulus. This polyphagous polypore has an indifferent distribution in Helsinki. In the outer areas it favours Salix caprea. The survival of $F$. punctata in the inner city is due to the wide host spectrum, which includes remarkably many exotic species, and to its ability to attack living trees. The species does occur as a parasite in the outskirts, but flourishes only after the hosts have died. In the inner city the parasitic habit becomes more striking, because dead woody material is soon removed. Figs. 23, 48 (map).

Fomitopsis pinicola (Sw.: Fr.) Karst.

Picea abies (54\%), Betula (19\%), Pinus sylvestris $(17 \%)$, Alnus glutinosa $(3 \%)$, Populus tremula $(3 \%)$, Sorbus aucuparia $(2 \%)$, Salix alba (1\%), also found on Alnus incana, Corylus avellana, Salix caprea and Tilia cordata. A distinctly peripheral species, very common in the forested outskirts. In its abundance $F$. pinicola is comparable to Fomes fomentarius, but it is more evenly distributed. On the islands and along the coast $F$. pinicola is mainly a parasite of pine, and a more serious killer of these trees than Porodaedalea pini. Inland records are mostly from spruce, and remarkably often from birches. In some areas of southern and central Finland $F$. pinicola parasitizes (otherwise very hardy) Tilia cordata, but that problem was not evident in Helsinki. T. $\times$ vulgaris seems to be much more resistant to the fungus than the indigen- 
ous $T$. cordata, a lucky coincidence for this greatly favoured park tree. $F$. pinicola is one of the most harmful decaying agents in the recreational forests of Helsinki. - Figs. 18, 36 (map).

F. rosea (Alb. \& Schw.: Fr.) Karst.

Picea abies (4 finds). The occurrences of $F$. rosea are very haphazard in the Helsinki area. Two records derive from the built-up centre, from timber in buildings. The others are from the outskirt forests, from spruce trunks. F. rosea is rather rare in southern and central Finland, but commoner in the north. Its distribution was mapped by Kotiranta and Niemelä (1981).

\section{Ganoderma lipsiense (Batsch) Atk.}

G. applanatum (Pers.) Pat.

Betula $(30 \%)$, Acer platanoides (19\%), Populus tremula $(17 \%)$, Quercus robur (5\%), Tilia (5\%), single records from Aesculus hippocastanum, Alnus glutinosa, A. incana, Alnus sp., Fagus sylvatica, Fraxinus excelsior, Laburnum alpinum, Populus $\times$ berolinensis, Prunus padus, Quercus sp., Salix caprea, S. fragilis, Sorbus, Tilia stellata, Ulmus glabra and Ulmus sp. The species is indifferent in its distribution, polyphagous as to its hosts, and is scattered over most of the study area. In the inner city $G$. lipsiense is predominantly parasitic, attacking Acer platanoides and other southern or exotic deciduous trees. Fruit bodies often emerge close to the ground and the fungus may be an important agent of butt- and root-rot in the parks. The mycelium stays alive after the tree is felled and fruit bodies are formed even on the underground stump remnants; in many such finds the hosts could not be identified. In the forests $G$. lipsiense is found mostly as a saprophyte of birch stumps. The species causes harm in Helsinki by decaying park trees. Its distribution in Finland was mapped by Niemelä and Kotiranta (1986). - Figs. 22, 49 (map).

G. lucidum (Curt.: Fr.) Karst.

Alnus glutinosa (1 find), Betula (1), Picea abies (1). The ecology and distribution in Finland were discussed by Niemelä and Kotiranta (1986).

\section{Gelatoporia subvermispora (Pil.) Niemelä}

Three finds in Helsinki (6678:386, 6679:387, 6682:397), on Picea abies, Quercus robur and Salix caprea. This rare species was discussed, mapped and illustrated by Niemelä (1985a).

Gloeophyllum abietinum (Bull.: Fr.) Karst.

Two finds (6674:391, 6678:394) on wood in buildings, evidently Pinus sylvestris. The species oddly favours dry, processed wood in contact with wet ground or water. Elsewhere in Finland it has been found on wooden bridges, lakeside quays, and fence posts driven into moist bog moss.

G. odoratum (Wulf.: Fr.) Imazeki

Picea abies (97\%), a single find on Pinus sylvestris. Peripheral, and in some areas fairly common. $G$. odoratum grows in dense spruce forests on large stumps that are still corticated, forming roundish knots on the even upper surface of saw-cut stumps. It is also found on large, dry, decorticated stumps left in clear-cut areas. The spongy fruit bodies absorb large amounts of water during rain, which may help them to survive dry periods.

G. sepiarium (Wulf.: Fr.) Karst.

Picea abies (76\%), Pinus sylvestris (20\%), Betula (2\%), single finds on Populus tremula and Salix caprea. Peripheral, very common in suitable sites. $G$. sepiarium is mostly found in dry, sunny localities: rock outcrops, forest clearings and roadsides, especially on spruce stumps. It is also often observed on outdoor wooden structures, and causes some harm for this reason. - Fig. 37 (map).

G. trabeum (Pers.: Fr.) Murr.

This polypore, not occurring in nature in Finland, has been collected several times in public and private saunas, on both softwood and hardwood (including the abachi, Triplochiton scleroxylon K. Schum.). Its intensive brown-rot causes harm by destroying wooden panels and benches; the fruit bodies are deformed but identifiable in the microscope. According to our map it is centric, but since it fruits indoors only, this interesting, thermophilic, southern species falls outside the scope of our study. G. protractum (Fr.) Imazeki, a northern species, has often been confused with it.

Gloeoporus dichrous (Fr.: Fr.) Bres.

Betula (57\%), Alnus incana (15\%), single records on Alnus glutinosa, Populus tremula, Salix caprea and Sorbus aucuparia. Rather rare and slightly peripheral, growing on wood first decayed by Inonotus obliquus.

Hapalopilus rutilans (Pers.: Fr.) Karst.

Sorbus aucuparia (56\%), Betula (33\%), Alnus incana (3\%), Salix caprea (3\%), single observations on Prunus padus and Salix sp. This is one of the few polypores that favour Sorbus as their host. The distribution is peripheral, but deviates from the pattern shown by most other polypores regarded as peripheral in our study; the finds were made 5-10 kilometres inland but parallel with the coastline, mostly in poor, dry, exposed pine forests on rock outcrops. The fruit bodies develop on thin stems and branches, standing or fallen, and the species is harmless. - Fig. 54 (map). 

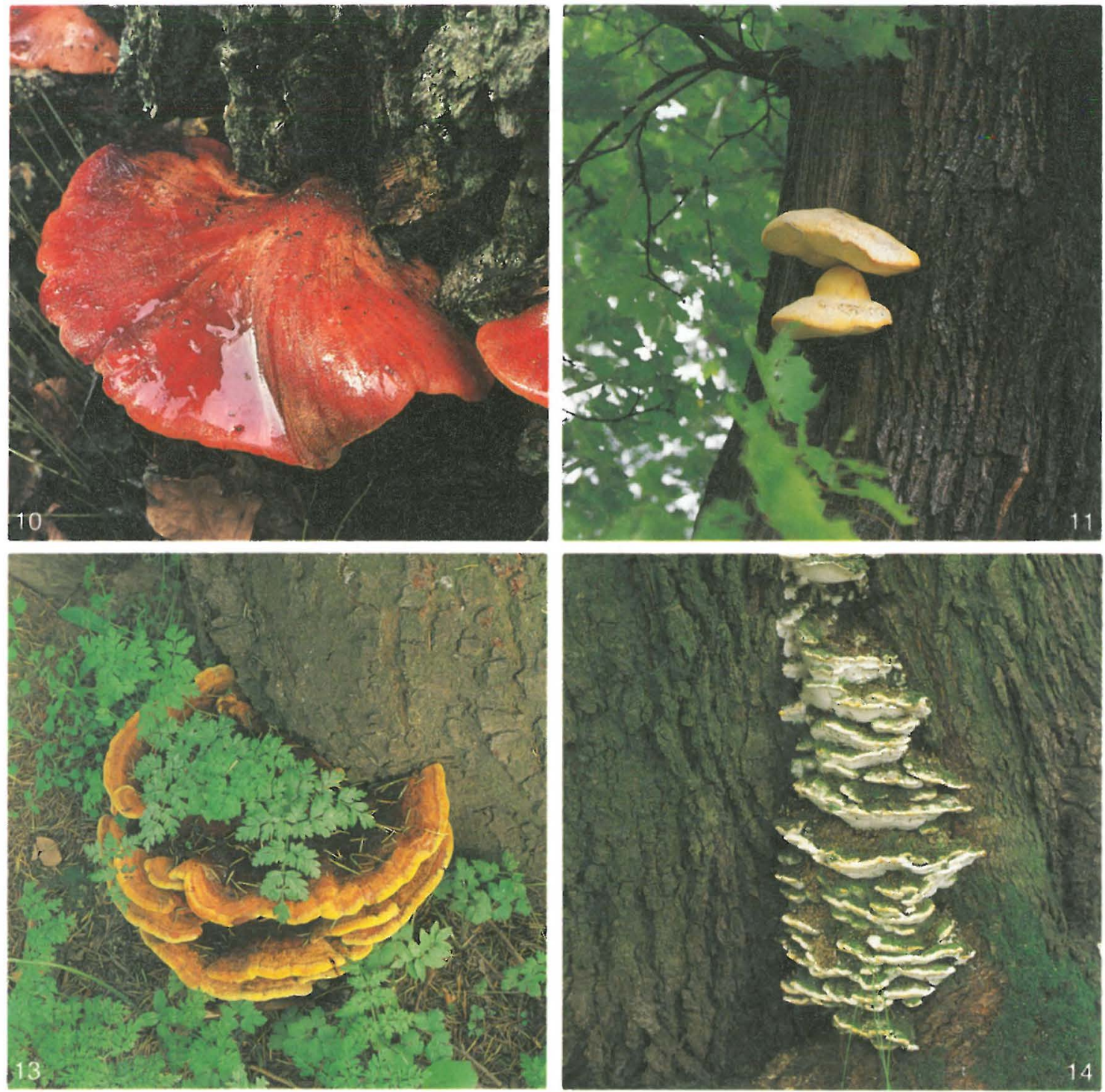

Figs. 10-15. Centric polypores. - 10: Fistulina hepatica. - 11: Spongipellis spumeus. - 12: Polyporus squamosus. - 13: Phaeolus schweinitzii. - 14: Rigidoporus populinus. - 15: Laetiporus sulphureus.

H. salmonicolor (Berk. \& Curt.) Pouz.

Pinus sylvestris (6679:391). Very rare in Finland, found only once during this study on a large, charred pine stump.

Heterobasidion annosum (Fr.) Bref.

Picea abies (86\%), Pinus sylvestris (4\%), Sorbus aucuparia (4\%), single records on Acer platanoides, Alnus incana, Betula and Tilia. A peripheral species, scattered to fairly common. It is especially harmful in the richer sites of the recreational forests, and may be even commoner than it appears to be because its scanty fruiting makes occurrence difficult to establish. Generally it is one of the most troublesome white-rot causing fungi in southern and central Finland (Laine 1976). H. annosum was treated here in a collective sense. - Fig. 41 (map).

Inocutis rheades (Pers.) Fiasson \& Niemelä

Populus tremula (8 finds). A rare species, growing almost exclusively on dead aspen-wood. 

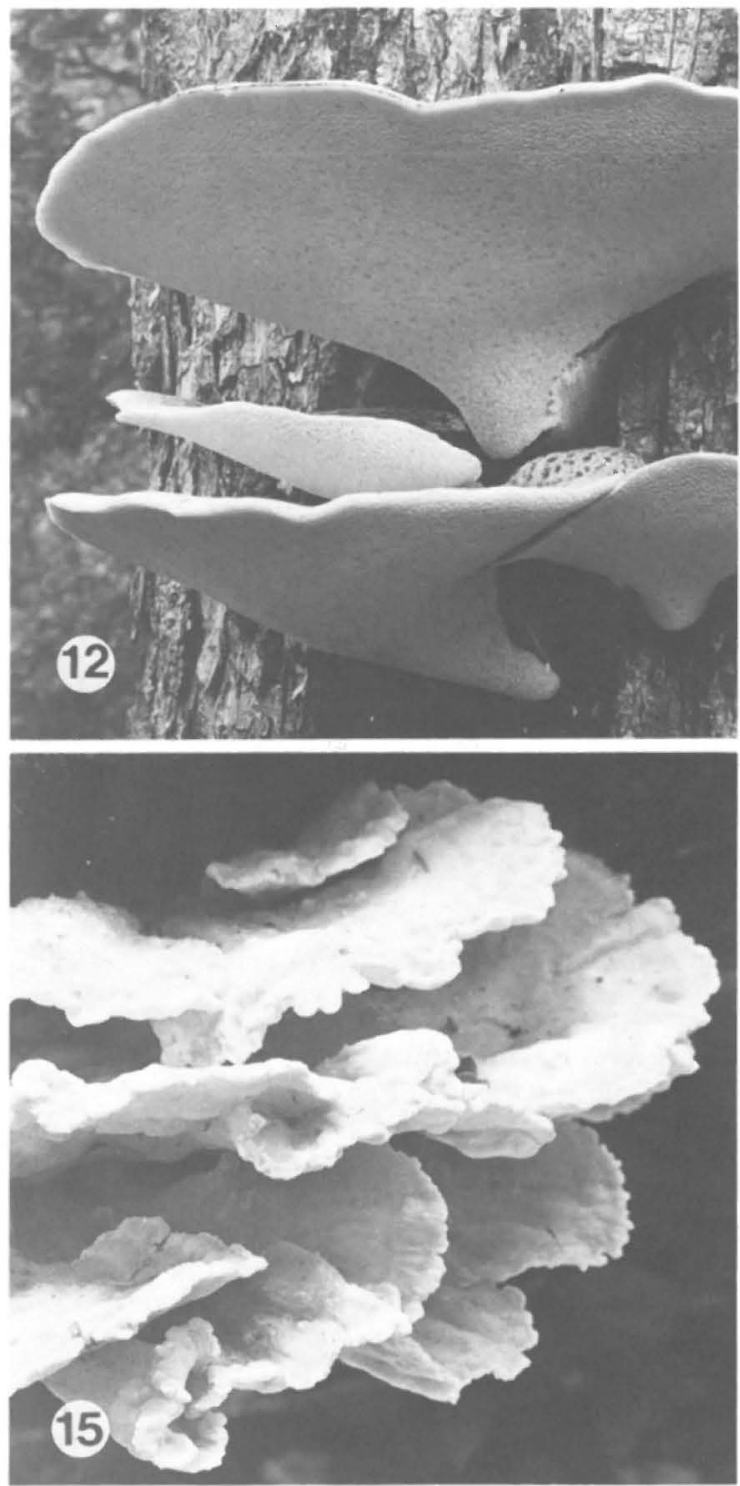

Inonotus obliquus (Pers.: Fr.) Pil.

Fruit bodies: Betula ( $82 \%)$, Alnus glutinosa (12\%), single finds on Alnus incana and Sorbus aucuparia. Imperfect knots: Betula (89\%), Alnus glutinosa (5\%), A. incana (4\%), Sorbus aucuparia $(2 \%)$. The resupinate fruit bodies of $I$. obliquus were found rather rarely, in peripheral areas only. In contrast, the black, imperfect knots are very common almost everywhere, and the species is thus indifferent in its distribution. It causes much harm on birch, especially in the innercity parks and sidewalk tree rows. For instance, the birches are heavily infested in the Sibelius, Tähtitorninmäki and Kaisaniemi parks, and I. obliquus is the main reason why Betula pendula is regarded as rather unsuitable for park plantings, in spite of its climatic hardiness and beautiful shape. Pruning makes the trees especially susceptible, but the fungus also invades them via frost cracks and bark holes made by borer beetles. - Fig. 50 (map).

\section{I. radiatus (Sow.: Fr.) Karst.}

Alnus glutinosa $(55 \%)$, A. incana (17\%), Betula $(7 \%)$, Populus tremula (6\%), Prunus padus (3\%), Sorbus aucuparia (3\%), Corylus avellana (2\%), Salix caprea (2\%), also on Alnus sibirica, Crataegus pringlei, Crataegus sp., Syringa vulgaris and Taxus cuspidata. The species has a special distribution pattern. It is very common along the coast in luxuriant, wet alder forests. The seashore thickets of alder are maintained by the slow but continuous land upheaval, and $I$. radiatus clearly benefits by this. The species was found only seldom in park trees and bushes. - Fig. 55 (map).

\section{Ischnoderma benzoinum (Wahl.) Karst.}

Picea abies (84\%), Pinus sylvestris (16\%). A scattered or fairly common, peripheral species. Its total range and ecology in Finland were discussed by Niemelä and Kotiranta (1986). - Figs. 19, 42 (map).

Junghuhnia collabens (Fr.) Ryv.

Picea abies (1 find). An old record (HFR) from a spruce stump. The exact locality is unknown.

\section{J. nitida (Pers.: Fr.) Ryv.}

Salix caprea (7 finds), Corylus avellana (3), single records on Alnus glutinosa, Populus tremula, Prunus padus and Sorbus aucuparia. A rare species, though locally numerous in Mustavuori. It favours thickets in site type V (idle land) and bushy grass-herb enclosures in site type IV (forests).

\section{J. separabilima (Pouz.) Ryv.}

Corylus avellana, Prunus padus, Salix caprea; woody debris under Acer platanoides, Salix caprea. Single records from two small areas (6680:389 and 6681:397). Laine (1967) reported the species (as Chaetoporus radulus) from Åland.

\section{Laetiporus sulphureus (Bull.: Fr.) Murr.}

Salix alba (4 finds), S. fragilis (3), Salix sp. (2), Fraxinus excelsior (1), Quercus robur (1), Quercus sp. (1). This is a species with a centric distribution. Almost all finds derive from old parks or old sidewalk tree rows. In southern Finland mostly an aggressive parasite of old oaks, the species has been observed in Helsinki predominantly on thick-stemmed willows. It infects living trees and first causes branch dieback and thinning of the crown. Fruit bodies emerge only in a late stage of deterioration, and the infected trees die with- 


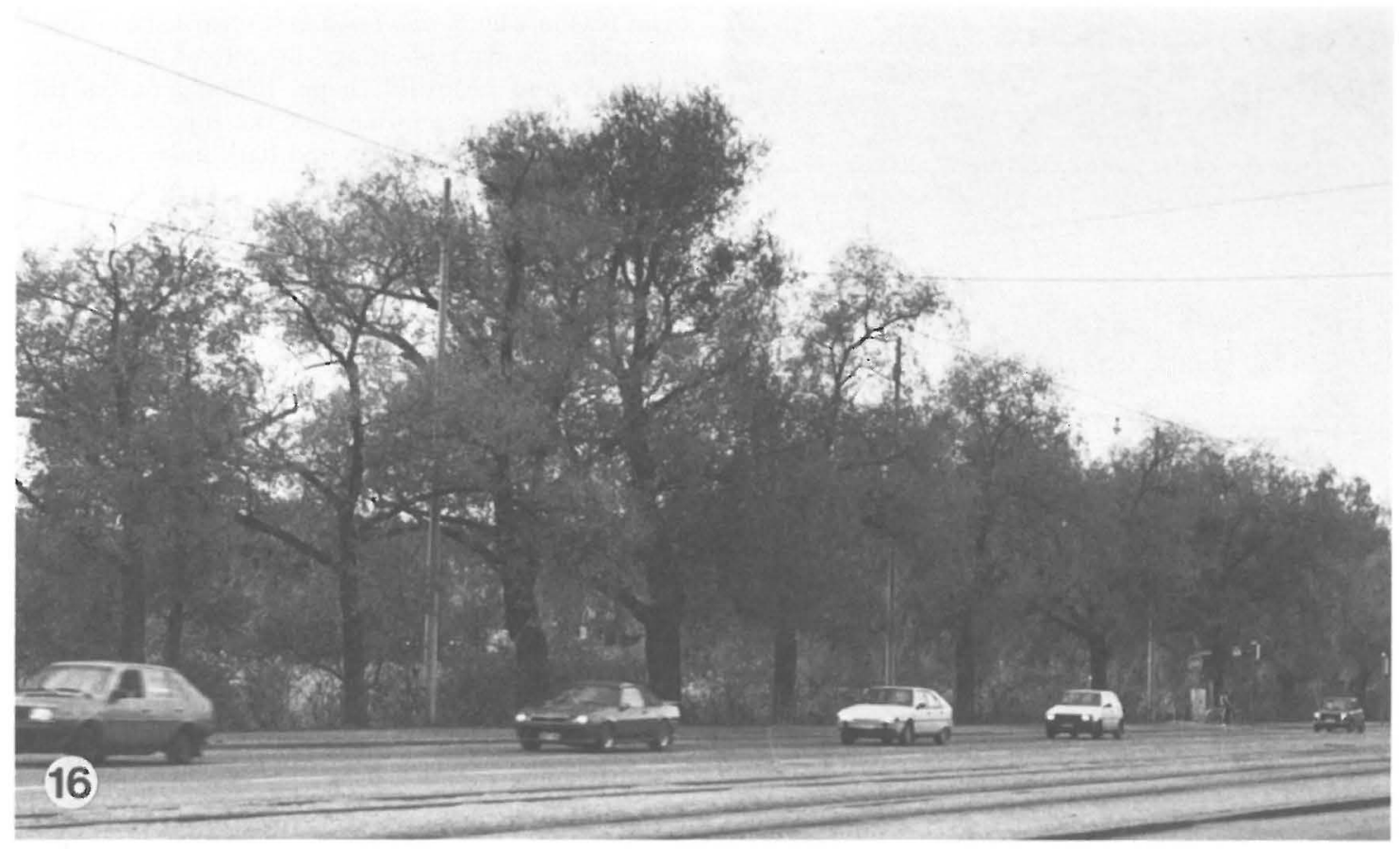

Fig. 16. A row of trees on Helsinginkatu (6676:385) showing differences in resistance. All the 30 Salix alba trees in the row are free from polypore fruit bodies, while the single $S$. fragilis (the tallest one with darker foliage) is heavily infested with Ochroporus igniarius.

in a few years after the first fructifications - if not removed earlier by city arborists. $L$. sulphureus has caused the loss of noble park trees, e.g. in the parks of Kaisaniemi, Ritarinkatu, Kaivopuisto and Kulosaari, and some of the trees have collapsed during autumn storms. The removal of certain infected trees has aroused strong protests from people living in the neighbourhood; this resistance is unjustified, however, because such trees are decayed throughout and will soon die. - Figs. 5, 15, 30 (map).

Lenzites betulina (L.: Fr.) Fr.

Betula $(94 \%)$, single record on Sorbus aucuparia. A scattered species and peripheral in Helsinki. It favours stumps of birch a few years old.

Leptoporus mollis (Pers.: Fr.) Quél.

Picea abies (5 finds), Pinus sylvestris (1). A rare species in the area. The Finnish distribution and host relationships were published by Kotiranta and Niemelä (1981).

Meruliopsis taxicola (Pers.) Bond.

Pinus sylvestris (1 find).
Ochroporus igniarius (L.: Fr.) Schroet.

Phellinus igniarius (L.: Fr.) Quél.

Betula (27\%), Salix caprea (18\%), Sorbus aucuparia (16\%), Alnus glutinosa (9\%), Acer platanoides (7\%), Salix fragilis (4\%), Salix sp. (4\%), Salix alba $(2 \%)$, Fraxinus excelsior (1.5\%), Sorbus intermedia $(1.5 \%)$, single records on Acer negundo, A. tataricum, Aesculus hippocastanum, Alnus incana, Corylus avellana, Crataegus sp., Juglans cinerea, Malus prunifolia, Prunus padus, Quercus rubra, Salix $\times$ blanda, S. myrsinifolia, $S$. pentandra. O. igniarius is a polymorphic and ecologically very flexible polypore with an indifferent distribution. In the outskirts it is predominantly a wound parasite or saprophyte, in the inner city more exclusively parasitic, and a very harmful pathogen of old park trees. Almost all the inner-city records represent $O$. igniarius var. igniarius, a robust, roundedged variety. In the forests the other varieties are commoner (cf. Niemelä 1975), including var. trivialis (Killerm.) Niemelä on thinner willows. Many of the old officially protected individuals of Salix fragilis and $S . \times$ blanda in the inner city are infected by this fungus. The frequency percentages are misleading as regards the relative hardiness of Salix alba: it is a commonly cultivated park and boulevard tree, while S. fragilis occurs as single individuals only. - Figs. 3, $16,21,51$ (map). 
O. laevigatus (Karst.) Fiasson \& Niemelä

Betula $(77 \%)$, single records from Alnus glutinosa, Salix caprea and Sorbus aucuparia. A rare or scattered, peripheral, saprophytic polypore on birch, very seldom occurring on other tree species. See Niemelä (1972) for the distribution in Fennoscandia. - Fig. 43 (map).

\section{O. lundellii (Niemelä) Niemelä}

Betula (3 finds), Prunus padus (2), Populus tremula (1), Salix (1). Very rare in the study area, saprophytic, peripheral. See Niemelä (1972) for the distribution in Fennoscandia.

\section{O. nigricans (Fr.) Fiasson \& Niemelä}

Betula (3 finds). An inhabitant of virgin northern forests, $O$. nigricans has been found only a few times in the outskirts of Helsinki. Its identification is difficult, and separation from the polymorphic $O$. igniari$u s$ is uncertain unless richly fertile fruit bodies are present.

\section{O. nigrolimitatus (Rom.) Fiasson \& Niemelä}

Picea abies ( 1 find). An exceptional guest in man-influenced environments, found on a fallen spruce trunk in the best-preserved part of the Mustavuori forest (6682:397). It is found more frequently in the virgin forests of northern and eastern Finland (Niemelä \& Kotiranta 1982).

\section{O. populicola (Niemelä) Niemelä}

Populus tremula ( 3 finds). This sapwood parasite of large aspen trees was found in peripheral Helsinki.

\section{O. tremulae (Bond.) Fiasson \& Niemelä}

Populus tremula (100\%). Scattered all over the study area. The distribution map also illustrates the occurrence of quaking aspen in Helsinki, since $O$. tremulae almost invariably inhabits every stand with fully grown aspen trees. The effects of this well-adapted parasite cannot be estimated externally because only the central column of the trunk becomes decayed and infected trees stay healthy-looking to the very end. Fig. 44 (map).

\section{O. tuberculosus (Baumg.) Fiasson \& Niemelä}

\section{Phellinus pomaceus (Pers.) Maire}

Prunus padus (2 finds), P. avium (1), P. insititia (1). This parasite of old cherry- and plum-trees may be commoner in the area, but its occurrence in private gardens makes documentation difficult. Its distribution in Fennoscandia coincides rather well with the northern limit of the Hemiboreal zone (Niemelä 1977).

\section{Oligoporus}

The concept of this genus has varied greatly, depending on who has used the name. Pouzar (1967, as Strangulidium; 1984) prefers a very restricted delimitation, comprising only O. rennyi (Berk. \& Br.) Donk and $O$. sericeomollis. Gilbertson and Ryvarden (1985) propose a much wider, less clearly defined concept, embracing well over 20 species. As the question is too complicated to be discussed here, we have very tentatively adopted an intermediary delimitation. The critical characters are the spore form and size (shortly cylindrical with truncate ends, roughly $4 \times 2 \mu \mathrm{m}$, $\mathrm{CB}+$ if thick-walled enough for the staining to become visible), the tendency to produce chlamydospores, the type of cystidia (if present; subulate, with capitate crystals), basidia having a slight central constriction, the spathulate, flabelliform or substipitate habit of the fruit bodies (in pileate species), the colour, consistency and some other macroscopical features.

O. balsameus (Peck) Gilbertson \& Ryvarden

U. Helsinki, Rajatorppa, fallen trunk of Betula, Grid $27^{\circ} \mathrm{E} 6684: 380$, 28.VIII.1981 Erkkilä 231 (T.N.).

This is the first Finnish collection that we could verify. Eriksson and Strid (1969) referred to a find from northern Finland, determined by V. Kujala as Tyromyces kymatodes (Rostk.) Donk: as far as we know, no material has been preserved and the record must remain uncertain. Norokorpi (1979), too, reported the species from northern Finland, on the basis of mycelial studies and a fruit body find, but there is no material to confirm the difficult identification.

O. cerifluus (Berk. \& Curt.) Gilbertson \& Ryvarden U. Helsinki, Laajasalo, on decayed stump of Picea abies, Grid $27^{\circ} \mathrm{E}$ 6674:392, 16.IX.1981 Erkkilä 286 (T.N.).

Fruit body pileate, roundish, flat, ca. $2 \mathrm{~cm}$ in diam, 3-4 mm thick, laterally adpressed to wood but attached only by a restricted, root-like base. Upper surface glabrous, cream-coloured and with several narrow, honey-coloured growth zones. Margin entire, acute, rolled downwards also in parts adpressed to wood. Lower surface deep cream to pale ochraceous, pores angular, (1-) $2(-3)$ per $\mathrm{mm}$, with thin and lacerate edges; tubes up to $3 \mathrm{~mm}$ long, flattening or splitting on drying. Context soft when fresh, firm when dry, white, 0.5-1 mm thick, homogeneous but slightly radially fibrillose. Taste slightly sour.

Monomitic, hyphae with clamp connections, structure best seen in CB. Context with thin-walled (especially near the surface) to subsolid (in strands) hyphae, (2-) 3-5 $\mu \mathrm{m}$ in diam, walls swelling inwards in $\mathrm{KOH}$. Dissepiments with tortuous, rather thickwalled, tightly packed hyphae, $2.5-3.5 \mu \mathrm{m}$ in diam. 
No cystidia. Spores cylindrical, obtuse-ended, often in tetrads, 3.9-4.5 $\times 2-2.2 \mu \mathrm{m}$, IKI-, very weakly $\mathrm{CB}+$ (plasma staining deep blue), with one distinct guttule. A few chlamydospores (ovoid, $\mathrm{CB}+$ ) found on the upper surface.

The identity of this specimen remained somewhat uncertain. Externally it resembles Polyporus cerifluus Berk. \& Curt. (holotype: [U.S.A., South Carolina,] 'Car. Inf., Ravenel 2926', K, examined) in having a thin context, long tubes and restricted attachment, and in tending to produce a downwards involute cap. The microscopy also fits, with the exception that the hyphae of the context retain their outer shape in $\mathrm{KOH}$, swelling only inwards so that they look almost solid. In the type they swell somewhat more strongly, and their outlines disappear.

$O$. cerifluus has not been reported by this name in Finland before; the type of Podoporia confluens Karst. ([U.S.S.R., Vyborg,] 'Myllysaari, i palmhus under en växthylla, 26.VIII.1892 Thesleff', Herb. P.A. Karsten $816, \mathrm{H}$, examined) is conspecific with it. In $\mathrm{H}$ there are some unpublished collections of this species from southern Finland.

O. floriformis (Quél. ex Bres.) Gilbertson \& Ryvarden Picea abies (2 finds), Pinus sylvestris (1), Betula (1), unidentified coniferous wood (1).

Pileate: spathulate, flabelliform or substipitate, 1$2 \mathrm{~cm}$ wide, $1-2 \mathrm{~mm}$ thick, projecting $1.5-2.5(-3.5) \mathrm{cm}$ from substrate, mostly in small, imbricate or rosettelike groups. Upper surface glabrous, straw-coloured and often with a pale smoke-brown band, when dry radially wrinkled and with a faint silky lustre. Margin entire or lobed, thin and acute, rolling down at outer edges. Lower surface white, when dry sordid strawcoloured and darker than the upper surface, pores round or angular, (4-) 5-6 (-8) per mm, with even edges; tubes $1-1.5 \mathrm{~mm}$ deep, in section slightly darker than the white context. Bitter.

Monomitic, hyphae with clamp connections. Context with distinct hyphae forming even and regular texture, 3-5 $\mu \mathrm{m}$ in diam; wall thickness uniform, under $1 \mu \mathrm{m}$, with minimal swelling in $\mathrm{KOH}$ (to $1 \mu \mathrm{m}$ ). Dissepiments with tortuous, thin-walled, rather tightly packed hyphae, $2-3 \mu \mathrm{m}$ in diam. No cystidia. Spores thickly cylindrical, obtuse-ended, single or in tetrads, (3.8-) 4-4.5 $\times 2-2.3 \mu \mathrm{m}$, IKI-, very weakly $\mathrm{CB}+$ (plasma staining faint blue), with one refractive guttule. Scattered chlamydospores (ovoid, 5.5-7 $\times$ 3.8-5.5 $\mu \mathrm{m}, \mathrm{CB}+$ ) found among pellicular hyphae in almost every section.

The few, scattered finds give no clue to regional preferences, but the sites belong mostly to types IV and V. Ecologically $O$. floriformis favours moist, shady, rich localities, emerging from partly buried or otherwise moist woody debris.

The species is mostly identified on its macroscopy, but difficulties arise if the habit is not clear enough. Spores offer little help, but the context has a characteristic, beautifully uniform texture, being composed of subparallel flexuose hyphae. They are richly clamped and of even diameter and even wall thickness; their appearance does not change significantly in $\mathrm{KOH}$. The narrow, tortuose, tightly packed hyphae of the upper dissepiments are thin-walled, in contrast to the thick-walled hyphae in $O$. cerifluus.

\section{O. ptychogaster (Ludw.) Falck \& O. Falck}

U. Helsinki, Viikki, stump of Picea abies, Grid $27^{\circ} \mathrm{E}$ 6681:391, 13.X.1980 Kotiranta 2622 \& Niemelä 2293 (T.N., H.K.).

Perfect fruit bodies pileate, spathulate or reniform, $1-3 \mathrm{~cm}$ wide, $5 \mathrm{~mm}$ thick, projecting $1.5-3 \mathrm{~cm}$, base constricted or narrowing into a rooting stipe. Upper surface glabrous or nearly so, soft, white (when dry cream to straw), when fresh with small, round, hygrophanous flecks. Margin rounded (tubes long, extending to the very edge). Lower surface white (dry: ochraceous-cream), pores elongated to sinuous, 2-3 (-4) per $\mathrm{mm}$, mouths ciliate and slightly dentate. Context in section ca. $1 \mathrm{~mm}$ thick, white, fibrillose; tubes cream, 3-5 mm long. Taste mild.

Imperfect fruit bodies hemispherical, white; when young with soft, tufty hairs, when mature disintegrating into ochraceous, powdery mass.

Monomitic, hyphae with clamp connections. Context hyphae variable in thickness $(2.5-6 \mu \mathrm{m}$ in diam), often collapsed (in CB), thin-walled, subparallel hyphae intermixed with disoriented ones; in $\mathrm{KOH}$ refractive, walls swelling variably (thin, to locally thickened, to solid-looking). Dissepiments with flexuose, thin-walled, loosely interwoven hyphae, $2-3 \mu \mathrm{m}$ in diam. No cystidia. Spores thickly cylindrical to subellipsoid, obtuse-ended, single or in tetrads, rather thick-walled, 4-4.5 (-5) $\times 2.2-2.6 \mu \mathrm{m}, \mathrm{IKI}-, \mathrm{CB}+$ (plasma faint blue), with an indistinct guttule. Chlamydospores (ovoid, $\mathrm{CB}+$ ) found variably on upper surface. Imperfect knots in young stage with strands of parallel hyphae and interspaces with richly branched, coily hyphae; the latter divide into chlamydospores during maturation.

The description is based on the above-mentioned material, containing both the perfect stage and an adjacent anamorph. It can be seen that the microscopy of $O$. cerifluus and $O$. ptychogaster are rather similar. Generally the species are separated by their habits; these preliminary descriptions were made to encourage a more critical approach. It seems that differences can be found in the contextual hyphae (more fragile and thin-walled in $O$. ptychogaster) and in the hyphae of the upper dissepiments (more widely spaced and thin-walled in $O$. ptychogaster). The spore walls are very thin and membranaceous in $O$. cerifluus, while they are a little thicker and hence stain more 

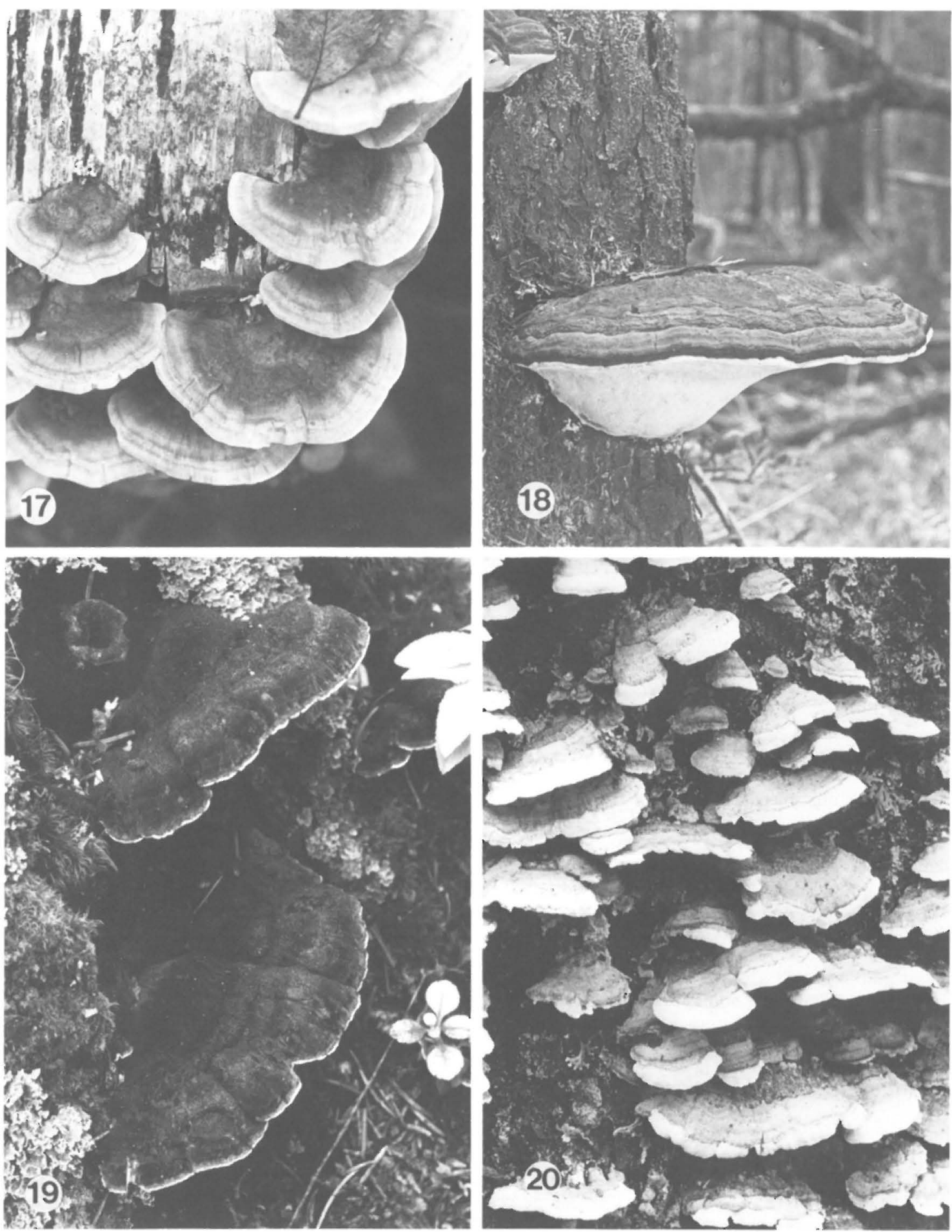

F1gs. 17-20. Peripheral polypores. - 17: Trametes multicolor. - 18: Fomitopsis pinicola. - 19: Ischnoderma benzoinum. 20: Trichaptum abietinum. 
distinctly in $O$. ptychogaster.

The species prefers old spruce stumps and rare finds have been made almost all over Finland.

O. sericeomollis (Rom.) Pouz.

Picea abies (3 finds). Rather rare in the study area. The spores of $O$. sericeomollis have thicker walls than those of the other species listed here under Oligoporus, and they are more strongly cyanophilous. The presence of cystidia with capitate encrustations (sometimes smooth) connects this species with $O$. balsameus.

Onnia leporina (Fr.) Jahn

Picea abies (3 finds). All records derive from Mustavuori (6682:397), possibly from a single tree. The species is northern in Finland (Niemelä \& Kotiranta 1983).

O. tomentosa (Fr.) Karst.

On ground (6680:389) from a single locality. This is a rare southern species (Niemelä \& Kotiranta 1983). The fruit bodies were growing in radial clusters around a spruce stump, being clearly located over the subterranean roots.

Parmastomyces transmutans (Overh.) Ryv. \& Gilbertson

Picea abies (6682:396), a single collection from the year $1950(\mathrm{H})$. This species has been found in a few localities in Finland (Ryvarden 1976, Kotiranta \& Niemelä 1981).

Perenniporia subacida (Peck) Donk

Picea abies (1 find), an old collection (year 1950, H), exact locality unknown.

Phaeolus schweinitzii (Fr.) Pat.

Larix sibirica $(44 \%)$, L. decidua $(28 \%)$, Pinus sylvestris $(22 \%)$, P. cembra ( 1 find). This is a rare species, and centric in Helsinki. The richest occurrence in the area is in the University Botanical Garden (Niemelä \& Erkkilä 1983), where fruit bodies have been observed and collected around several larch-trees for almost a hundred years. Some finds derive from old pines along the coast. The trees do not seem to suffer much from this root parasite. $P$. schweinitzii is rare in Finland (Niemelä \& Kotiranta 1986), but is found in all parts of the country. - Figs. 13, 31 (map).

Phylloporia ribis (Schum.: Fr.) Ryv.

Ribes uva-crispa (6671:388, 6681:382). Hiding in private gardens, this tiny polypore is even more difficult to study than Ochroporus tuberculosus. It has been found in a few scattered localities in Finland (Niemelä \& Kotiranta 1982), recently also in the town Porvoo, $50 \mathrm{~km}$ east of Helsinki. - Fig. 26.
Physisporinus rivulosus (Berk. \& Curt.) Ryv.

Pinus sylvestris (6679:387). A very rare species, reported recently from two localities in Finland (Kotiranta 1985). The transfer of the annual, watery species of the former Rigidoporus to Physisporinus seems to be well-founded. The remaining species of Rigidoporus come so close to Oxyporus that we cannot but accept Pouzar's (1966) proposal that the genera should be united. Ryvarden and Johansen (1980) described the type species and discussed the differences, but preferred to keep the genera separate.

P. sanguinolentus (Alb. \& Schw.: Fr.) Pil.

Pinus sylvestris (6679:387), timber in building. Laine (1967) has reported the species from Aland.

P. vitreus (Pers.: Fr.) Jülich

Alnus incana (1 find), unidentified deciduous wood (1). A very rare species, found in two localities (6681:391, 6678:394). See the note in Kotiranta and Niemelä (1981).

Piptoporus betulinus (Bull.: Fr.) Karst.

Betula $(100 \%)$. A very common species in the area; peripheral, though there are scattered records from the outer city centre. $P$. betulinus is a very harmful parasite of birch in forests and recreational areas. Its true occurrence is not easy to estimate, because the fruit bodies emerge only after the tree has died, and such trees are soon removed. - Fig. 38 (map).

\section{Polyporus}

This genus will be dealt with in the near future in the series of papers on Finnish polypores and is discussed only briefly here.

P. badius (Pers.) Schw.

Acer platanoides (6675:386), strongly decayed stump remnants on lawn. New to Finland. Found by Heikki Kotiranta. - Fig. 27.

\section{P. brumalis Pers.: Fr.}

Sorbus aucuparia (51\%), Betula (33\%), Populus tremula (9\%), Alnus glutinosa (6\%). Fairly common, peripheral, favouring site type $\mathrm{V}$.

P. ciliatus Fr.: Fr.

Sorbus aucuparia (38\%), Salix caprea (23\%), Betula (14\%), Alnus glutinosa (10\%), single records from $A$. incana, Malus domestica, Populus tremula, Salix sp. and Quercus robur. Scattered, peripheral, ecologically resembling $P$. brumalis. The concept includes $P$. lepideus Fr., which should be treated merely as a form of P. ciliatus (Esser \& Hoffmann 1977).

P. melanopus Pers.: Fr.

On ground under Betula, seldom under Corylus avel- 
lana, Prunus padus and Quercus robur, rare. In most cases the host could not be definitely ascertained.

\section{P. squamosus Huds.: Fr.}

Ulmus glabra (43\%), Fraxinus excelsior (21\%), Tilia $(14 \%)$, single records from Acer platanoides, Salix caprea, Ulmus glabra f. exoniensis and Ulmus sp. This spectacular polypore is one of the best examples of the centric species. $P$. squamosus is well established in most parks in the old part of Helsinki and many of the outer localities resemble the centric environments. The ashes on the island Suomenlinna support a steady population, the site belonging to the centric type. Most finds in mainland Helsinki are from elms, and Ulmus is by far the most favoured host genus. The species occurs predominantly as a parasite of large old trees. Fruit bodies emerge from scars left by pruned-off or broken branches, often high in the crown. It seems that the late removal of large trunk branches makes the trees especially susceptible. The fungus causes extensive heart-rot, which results in hollowing of big trunks. Infected trees continue to grow well, however, their outer wood layers remain sound, and they retain their ornamental value for a long time. Therefore we do not regard the fungus as a great nuisance, although it is locally common in parks. - Figs. 12, 32 (map).

\section{P. tubaeformis Karst.}

?P. picipes Fr. sensu orig, non auct.

Alnus incana (2 finds), Betula (1), Salix myrsinifolia (1), Salix sp. (1). Rare, peripheral. The nomenclature of this small, funnel-shaped polypore with reddish and darkening upper surface should be elucidated; the microscopical and macroscopical differences are constant and clear enough for its separation from $P$. badius, $P$. melanopus and $P$. varius. Its distribution extends over the whole of Finland.

\section{P. umbellatus Pers.: Fr.}

Stump of deciduous tree (1 find). Extinct in the area. The species was recorded south of the Käpylä district (6678:385) by Reima Saarenoksa on 24.VII.1974 (no collection). Since then, the new suburb of Itä-Pasila has been built on the site, and the original vegetation has been completely destroyed. The other finds in Finland have been published by Niemelä (1978) and Kotiranta \& Niemelä (1981).

\section{P. varius Pers.: Fr}

Acer platanoides (44\%), Fraxinus excelsior (22\%), single records on Betula, Corylus avellana, Salix myrsinifolia, Sorbus aucuparia, Tilia platyphyllos and Tilia species. Rare, the distribution showing a centric tendency. $P$. varius is also found frequently in old manor parks in outer Helsinki.
Poria placenta (Fr.) Cooke

Picea abies (6679:387). See Niemelä (1978b) and Kotiranta and Niemelä (1981) for earlier records.

Porodaedalea chrysoloma (Fr.) Fiasson \& Niemelä

Picea abies (3 finds). A northern species in Finland (Niemelä \& Kotiranta 1982), and collected only seldom along the southern coast. Two finds from Helsinki are over 50 years old, but a recent find was made during this study in eastern coastal Helsinki (6674:392)

\section{P. conchata (Pers.: Fr.) Fiasson \& Niemelä}

Salix caprea (90\%), Syringa vulgaris (4\%), single records on Alnus glutinosa, A. incana, Crataegus intricata, Crataegus sp., Lonicera xylosteum, Populus tremula, Prunus padus and Salix alba. A hemerophilous species, common in suitable sites (especially site type $\mathrm{V})$, having an indifferent distribution pattern. Almost all finds from the outskirts are from Salix caprea; in the inner city the fungus parasitizes numerous thinstemmed ornamental trees, especially Syringa.

\section{P. pini (Brot.: Fr.) Murr.}

Pinus sylvestris (100\%). This specialist on old, living pines has an exceptional distribution pattern. It has been noted fairly regularly in pine forests on the coast and the rocky, barren outer islands, but is absent inland, although pine is found abundantly there also. Till the 1860s it occurred in the coastal inner city, too, but now suitable trees are too few there, and its occurrence is therefore peripheral. The reason for the coast-dominated distribution is unknown to us. It is possible that strong winds blowing from the sea break off branches and expose the trees to infection; due to the abundant illumination in the archipelago, the trees are densely branched. Inland trees have a more upright crown structure with better vertical clearance: the lower branches remain thin, dying and soon falling off and their small scars callus over readily. Fig. 56 (map).

\section{Pycnoporellus fulgens (Fr.) Donk}

Alnus glutinosa (1 find), Betula (1), Picea abies (2). From three localities (6675:390, 6679:380, 6682:397) adjacent to the town borders. The species was discussed extensively by Niemelä (1980). - Fig. 25.

Pycnoporus cinnabarinus (Jacq.: Fr.) Karst. Sorbus aucuparia (63\%), Betula (19\%), Populus tremula $(11 \%)$, Salix caprea $(7 \%)$. Peripheral and found especially on rocky, pine-dominated forests (cf. Hapalopilus rutilans) on thin, dead, standing trunks of Sorbus. On Betula it is mostly found in areas where a coppice has been cut down, on dry trunk remnants. It does not usually grow on stumps. - Fig. 45 (map). 
Rigidoporus corticola (Fr.) Pouz.

Oxyporus corticola (Fr.) Ryv.

Populus tremula (46\%), Sorbus aucuparia (27\%), occasionally on Alnus incana, Betula, Malus, Prunus padus and Salix caprea. A scattered or rare saprophyte of the outskirts.

R. populinus (Schum.: Fr.) Pouz.

Oxyporus populinus (Schum.: Fr.) Donk Acer platanoides $(57 \%)$, Sorbus aucuparia $(7 \%)$, Salix caprea (6\%), Alnus glutinosa (5\%), Betula (5\%), Acer negundo (3\%), Acer sp. (3\%), Tilia sp. (3\%), Ulmus glabra (3\%), single finds on Acer platanoides 'Schwedleri', Aesculus hippocastanum, Betula papyrifera, Carya alba, Corylus avellana, C. colurna, Juglans regia, Malus baccata, Quercus robur, Quercus sp., Salix myrsinifolia and Ulmus pumila. $R$. populinus is a very common, centric species, preferring the host genus Acer even more than appears from the frequency percentage (cf. note in Materials and methods). Virtually all adult maples in the city are infected. Fruit bodies appear on furrows at branch joints, scars left by fallen branches, frost cracks, etc., and in old trees also inside the large cavities in the trunks. In good natural sites in southern Finland, Acer platanoides easily reaches the age of 150 years, but in the parks of Helsinki it can seldom be kept for more than 80 years. At first the decay proceeds slowly, and the trees may be left for several decades after the first fruit bodies appear. Finally, however, the fungus causes such extensive decay that larger branches collapse under damp heavy snow in autumn. Entire boulevards in the downtown area have been replanted for this reason in recent years. The fungus is economically very harmful, because Acer platanoides is one of the favourite sidewalk and park trees, due to its early flowering, beautiful shape and bright autumn colours. - Figs. 14, 33 (map).

Schizopora paradoxa (Schrad.: Fr.) Donk

Prunus padus (3 finds), Salix caprea (3), Salix sp. (2), Sorbus aucuparia (2), Alnus incana (1), Picea abies (1), Populus tremula (1), Quercus robur (1). A typical inhabitant of site type $V$ (thickets) and grass-herb enclosures in site type IV (forests).

S. radula (Pers.: Fr.) Hallenb.

Alnus glutinosa (31\%), Prunus padus (20\%), Quercus robur (15\%), Alnus incana (11\%), Betula (8\%), Sorbus aucuparia ( $8 \%$ ), Salix caprea $(4 \%)$, one record on Acer platanoides. Hallenberg (1983) described the differences between $S$. paradoxa and $S$. radula and found that the latter is commoner in coastal areas. We can confirm this: $S$, radula is commoner in our study area. The two species favour similar growth sites. $S$. radula is here reported as new to Finland. Mr Reima Saarenoksa (University of Helsinki) deserves our special thanks for revealing the occurrence and hosts of this species, and for studying the characteristics for the separation of the two species.

Skeletocutis amorpha (Fr.) Kotl. \& Pouz.

Picea abies (75\%), Pinus sylvestris (25\%). A fairly common, peripheral species, with remarkably patchy occurrences, mostly on stumps. - Fig. 57 (map).

S. nivea (Jungh.) Keller

Betula (1 find), Corylus avellana (1), Prunus padus (1), Salix caprea (1). These localities (6678:386, 6680:389, $6681: 391,6681: 397)$ harbour the easternmost records of the species in Finland. Laine (1967) reported it from Åland; only a few localities are known outside the Aland archipelago, along the southern coast.

\section{S. odora (Sacc.) Ginns}

\section{S. tschulymica (Pil.) Keller}

Picea abies (2 finds: 6678:395, 6679:380). A northern species, earlier reported from Finland by Kotiranta and Niemelä (1981) and Niemelä (1985a).

S. subincarnata (Peck) Keller

Pinus sylvestris (6679:387), processed wood.

Spongipellis spumeus (Sow.: Fr.) Pat.

Acer platanoides (2 finds), Aesculus hippocastanum (1). A parasitic species with centric distribution. The total distribution in Finland is southern (Niemelä 1978b). S. spumeus was found in Helsinki in the early 1960s, on a maple at Bulevardi 8 , and was collected there almost annually (HFR). Fruit bodies emerged from a branch scar ca. $2.5 \mathrm{~m}$ up the tree. In autumn 1972 the tree collapsed across the street and tramway lines, and was removed. To our delight, the fungus has now been found in two other localities. In these cases, also, fruit bodies emerge from scars on living trees, 2-3 $\mathrm{m}$ above the ground. - Figs. 11, 34 (map).

\section{Spongiporus caesius (Schrad.: Fr.) David}

Picea abies (83\%), Populus tremula $(8 \%)$, single records on Acer platanoides, Pinus sylvestris and Sambucus racemosa. A scattered, peripheral species. Fig. 46 (map).

\section{S. fragilis (Fr.) David}

Picea abies (3 finds), Pinus sylvestris (3), unidentified coniferous wood (1). Rare, peripheral.

S. guttulatus (Peck) David

Picea abies ( 5 finds). Rare, peripheral. Discussed by Niemelä (1978b). - Fig. 28.

S. leucomallellus (Murr.) David

Picea abies (6681:397). Rare, peripheral. See Niemelä (1978b) and Kotiranta and Niemelä (1981) for the general distribution in Finland. 

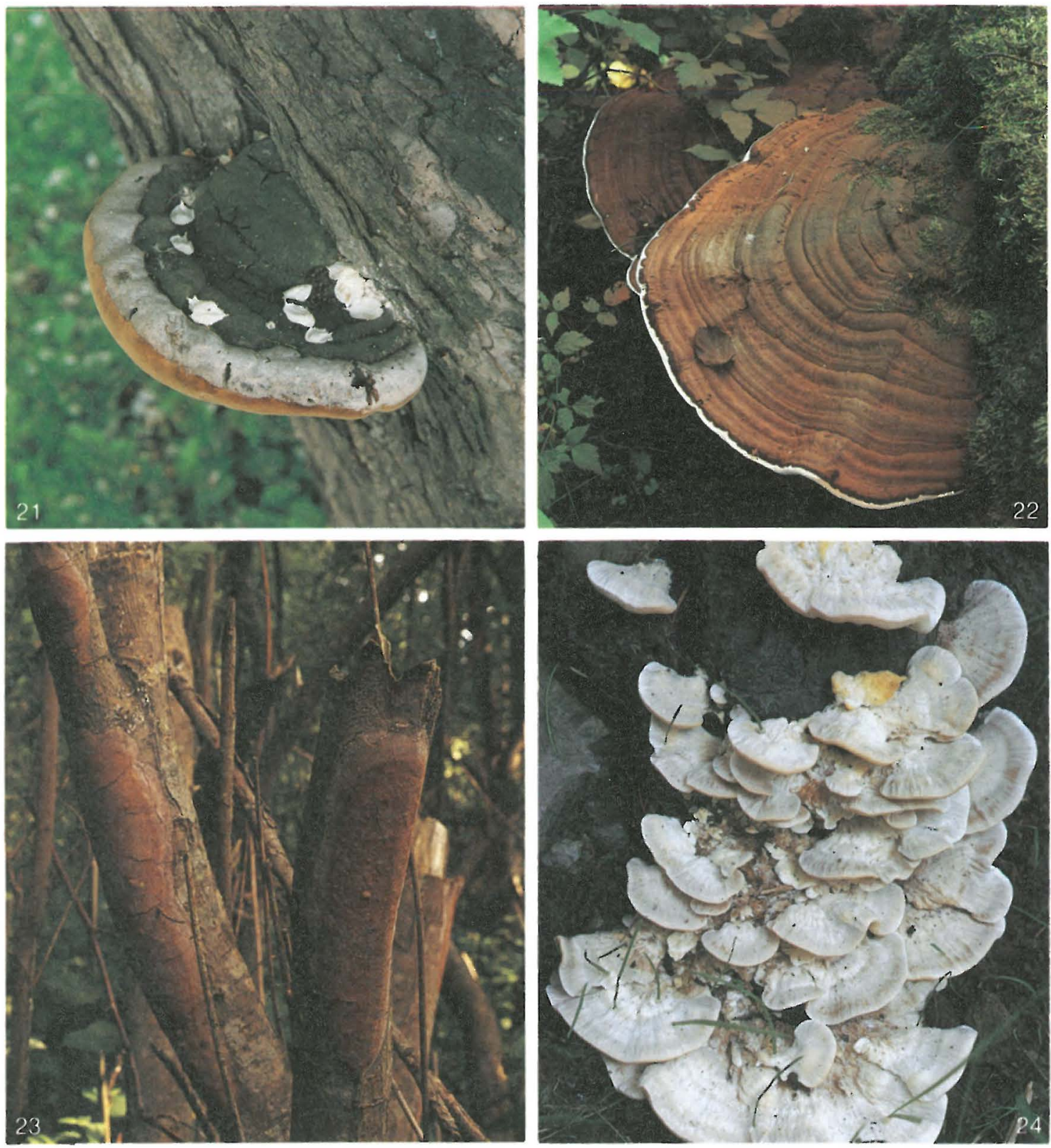

Figs. 21-24. Polypores having an indifferent distribution in Helsinki. - 21: Ochroporus igniarius. - 22: Ganoderma lipsiense. - 23: Fomitiporia punctata. - 24: Trametes pubescens.

\section{S. stipticus (Pers.: Fr.) David}

Picea abies ( $89 \%)$, Pinus sylvestris (11\%). Fairly common, especially in the outskirts of Helsinki.

S. subcaesius (David) David f. 'minor' Jahn (n.inval.) Populus tremula (3 finds), Alnus incana (2), Betula (2), Salix caprea (1). Finds scattered over the forest areas in Helsinki. The taxonomy of this small polypore has not been worked out satisfactorily.

S. tephroleucus (Fr.) David

Picea abies (5 finds), Sorbus aucuparia (2), Abies sibirica (1), Alnus incana (1), Betula (1). Scattered, peripheral. See the note on Tyromyces chioneus. 
S. undosus (Peck) David

Picea abies (6681:397). Very rare throughout Finland, first reported by Kotiranta and Niemelä (1981).

Trametes hirsuta (Wulf.: Fr.) Pil.

Sorbus aucuparia (38\%), Betula (28\%), Salix caprea (13\%), Populus tremula (9\%), Alnus incana (4\%), A. glutinosa $(3 \%)$, Prunus padus $(3 \%)$, also recorded on Acer platanoides and Quercus robur. Scattered or fairly common in Helsinki. The species is flexible ecologically and has an indifferent distribution pattern. $T$. hirsuta is a saprophyte of wooden debris, found also on dry, standing trees and poles made of hardwood.

\section{T. multicolor (Schaeff.) Jül.}

T. zonatella Ryv.

Betula (56\%), Populus tremula (24\%), Picea abies (?16\%), single records on Corylus avellana, Pinus sylvestris, Quercus robur, Salix caprea, S. fragilis, Salix sp., Sorbus aucuparia, Tilia sp., Ulmus glabra and $U$. laevis. A very common species in the whole of Finland, also in the study area. The distribution is peripheral, but due to its general abundance, it is absent from only a small area in the inner city. Distinct favourites of this saprophyte are birch and aspen; we somewhat doubt the high rating of spruce above. Some of the hosts were checked microscopically, but it is possible that stumps of Alnus glutinosa have sometimes been misidentified as spruce: they finally develop very similar bark. - Figs. 17, 39 (map).

T. pubescens (Schum.: Fr.) Pil.

Betula (22\%), Salix alba (15\%), Sorbus aucuparia $(15 \%)$, Tilia $\times$ vulgaris $(15 \%)$, single finds on Acer platanoides, Alnus glutinosa, Crataegus elliptica, Populus tremula, Prunus padus and Salix caprea. A rather rare species in Helsinki, indifferent with a slight centric tendency. $T$. pubescens is found mostly on dead birches and rowan-trees, but occurs downtown on various exotic hosts. Some of the latter finds derive from large branch scars on vigorous trees. - Figs. 24, 52 (map).

T. suaveolens (Fr.) Fr.

Populus tremula (1 find), Salix alba (1), S. fragilis (1). T. suaveolens is rare in Finland (Niemelä 1978b) and generally southern. It was found twice during this study $(6676: 385,6679: 383)$, and one old collection has been preserved in $\mathrm{H}$; the exact situation of the latter is unknown. All the records in Finland imply a centric distribution.

T. velutina (Fr.) Cunningh.

Betula (39\%), Alnus glutinosa (15\%), Salix caprea (15\%), single finds on Acer platanoides, Alnus incana, Salix sp. and Syringa vulgaris. The distribution is peri- pheral or indifferent, but the scattered finds do not give a clear picture. T. velutina grows as a saprophyte on various kinds of fallen hardwood material, also on strongly decayed stumps. The fruit bodies differ from those of $T$. pubescens in being thinner, softer and rapidly deteriorating, and in having a slight silky lustre when dry. These two taxa deserve critical comparison, including pairing tests.

T. versicolor (L.: Fr.) Pil.

Betula (3 finds), Populus tremula (2), Alnus glutinosa (1), A. incana (1), Malus sp. (1). This is a rare southern species in Finland, hemerophilous and indistinctly centric in its distribution.

Trichaptum abietinum (Pers.: Fr.) Ryv.

Picea abies (57\%), Pinus sylvestris (41\%), single records on Alnus incana, Betula sp. and Sorbus aucuparia. T. abietinum is very common in the area, and distinctly peripheral. It fairly rapidly occupies fallen trees, fresh woody debris in clear-cut areas, and new stumps. On pines it is often accompanied by $T$. fuscoviolaceum. The two are easily separated in fresh condition. - Figs. 20, 40 (map).

T. fuscoviolaceum (Ehrenb.: Fr.) Ryv.

Pinus sylvestris (92\%), Picea abies ( $8 \%$ ). Less common than the preceding species, though not rare in suitable sites. The distribution is peripheral and the pattern is exceptional if compared with the occurrence of pine in the area. For some reason, the abundant pine stands along the coast seem unsuitable for this polypore (cf. the maps of $T$. fuscoviolaceum and Porodaedalea pini!). Most inland finds derive from rather dry sites, and the species may avoid the most humid localities, the seaside included. - Fig. 58 (map).

Tyromyces chioneus (Fr.) Karst.

Sorbus aucuparia (5 finds), Betula (3). Surprisingly few records were obtained. Identification in the field has proved troublesome, and we are looking forward to a thorough comparison between this taxon and Spongiporus tephroleucus.

\section{Discussion}

\section{General remarks}

The ecological characteristics of urban environments have been discussed by Sukopp and Werner (1983). Polypores occupy a niche which is isolated from most of the general environmental factors, and the atmospheric contaminants in metropolitan areas can hardly affect them directly. Trees struggling with adverse environmental conditions are obviously more susceptible to attack by pests, and so the impact of urban environments on wood-rotting fungi is indirect, re- 
flecting the environmental tolerance of the hosts (Cooke \& Rayner 1984).

Polypore mycelia are commoner in park trees than in forest trees. In site type I (parks proper) in inner Helsinki, 70-75\% of the trees have decay in their trunk columns (Teuvo Hytönen, pers.comm.). In site type II (tree rows), over $90 \%$ of the trees have trunk rot: almost $100 \%$ of the trees over 80 years suffer from wood-rotting fungi, and decay is common in even the youngest tree age classes. In Germany about half of the fungi causing rot in park trees are polypores (Seehann 1979). The importance of this fungal group is increased by the fact that many of them are pioneer organisms, which invade sound wood, while the agarics and other groups are predominantly saprophytes, occupying wood in a later stage of decay.

Despite their common occurrence, polypores are less evident in parks, sidewalk trees and park forests than outside city areas. The reason is that in urban trees larger dead and heavily infected branches are removed, which hinders fruit body formation, although the trunk is undergoing decomposition. Our fruit body studies suggested that Tilia $\times$ vulgaris and Salix alba were very resistant to wood-rotting fungi, but our discussions with the city arborists (Pekka Jyränkö, Teuvo Hytönen, pers.comm.) revealed that they are very frequently decayed inside.

The occurrence of wood-rotting fungi on tree trunks could be estimated only by studying cultures on fresh wood samples, but that method was not applied in this study. Norokorpi (1979) obtained a detailed picture of decay-causing fungi by identifying cultures on northern Finnish spruce stands. Such a study would be very welcome in Helsinki also.

Altogether 120 polypore species were recorded from Helsinki. This is a remarkably high number, compared with the records from any other area of corresponding size in Finland. The species listed by Kotiranta and Niemelä (1981) from old forests in southern Central Finland totalled 97 and the polypores known to occur in the country at present number ca. 185 (Niemelä 1986). These figures clearly illustrate the mycofloral richness resulting from the combination of urban and well-preserved rural environments. On the other hand, comparison of the present list with that of Kotiranta and Niemelä (1981) shows that human influence has eliminated many rare species of old forests.

\section{Distribution patterns}

Although this is far less marked than among lichens, our maps reveal different distribution patterns among polypores in an urban area. We proposed three tentative pattern types - centric, peripheral and indifferent. The maps are grouped accordingly, showing some of the clearest examples. We will now discuss the distributional types and the possible reasons for the differences.

Centric. A small but characteristic group of polypores revealed a centric pattern (Figs. 29-34). Some of the species have a southern general distribution in Finland: Fistulina hepatica (Niemelä \& Kotiranta 1986), Laetiporus sulphureus and Spongipellis spumeus. Others have a southern concentration but also have rare or scattered records from central and northern Finland: Phaeolus schweinitzii (Niemelä \& Kotiranta 1986), Polyporus squamosus and Rigidoporus populinus. A less marked centric tendency was observed in several other species, e.g., Bjerkandera fumosa (Fig. 53), Daedalea quercina, Gloeophyllum trabeum, Polyporus varius, Trametes suaveolens and $T$. versicolor. These mostly have additional occurrences in old manor parks (Fig. 1), which, however, closely resemble the parks in the old city centre. Almost all extra-central finds of $P$. varius and $D$. quercina derive from manor parks, and these also harbour many occurrences of $R$. populinus.

It is interesting to speculate on the reasons for this preference of urban environments. The consequences of human activity are less evident than, for instance, in the case of lichens, and we can only suggest some possibilities. The development of this type of distribution is clearly due to a number of factors.

Urban areas change climatically into 'heat islands', having 1-2 degrees higher mean annual temperatures (Sukopp \& Werner 1983) and even more pronounced peak differences during the coldest winter periods. It is tempting to link this with the common occurrence of many southern polypores in the inner city of Helsinki. Climate does have a direct effect on the distribution of some polypores, e.g. Ochroporus tuberculosus (Phellinus pomaceus: Niemelä 1977). It is more probable, however, that the effect is indirect, reflecting the abundance of southern tree species and cultivars in the area, plus some other unknown factors.

The downtown concentration of some generally rare but widespread fungi is especially difficult to explain. Their hosts are widely distributed, but it may be that they reach a sufficient age only in the city parks, as in the case of Acer platanoides supporting Rigidoporus populinus. Concentration of Polyporus squamosus in the inner city has been observed not only in Helsinki, but also in Turku (SW Finland), where it is becoming commoner all the time (Seppo Huhtinen, pers.comm.). Ławrynowicz (1982) reported that the species is characteristic of the inner city of Łódź in Poland. The presence of suitable hosts in great numbers in a small area seems to promote its establishment, while it is less successful in areas where the hosts are far apart. The effectiveness of longdistance dispersal in lignicolous fungi has surely often been overestimated. 
Some general remarks can be made about the centric species. Many of them favour exotic trees or at least exotic provenances and cultivars. They mainly favour hardwoods, and tend to parasitize large, old, living trees. Their mycelia are often slow-growing but long-living and so they mostly decay heartwood, seldom killing the trees. The only aggressive killer in this group is Laetiporus sulphureus. Ecologically they prefer or at least tolerate dry, open, well-illuminated, windy sites. Most centric polypores produce annual fruit bodies, which obviously results from the care given to urban trees: rapidly wilting fruit bodies are easily overlooked, but trees bearing perennial conks are apt to be removed. The pruning of old trees surely provides the main route of infection in this group of polypores.

Peripheral. A very great proportion of the polypores revealed a distributional pattern that can be described as peripheral. The clearest representatives of this group do not occur in the inner city at all; the others show a more or less distinct decrease in abundance from site type IV through V, III and II to I. The maps on pages 31 and 32 show different variations of this theme (Figs. 35-46).

The factors responsible for the peripheral pattern depend on the species. The slowly established, weak competitors inhabiting old forests can persist only in the last peaceful spots remaining in the outskirts (Ochroporus nigrolimitatus, Pycnoporellus fulgens). Robust saproparasites, fruiting predominantly after the host has died (Fomes fomentarius, Fomitopsis pinicola, Piptoporus betulinus) are soon eradicated from urban centres. Specialists on trees which are not grown in town areas (Ochroporus tremulae, Hapalopilus rutilans) remain in the outer forests. Pioneer saprophytes that colonize sound sapwood during the first 2-3 years after the tree's death (Trichaptum abietinum, T. fuscoviolaceum) find it difficult to gain a foothold in the parks, as do also the annual, saprophytic fungi belonging to the late stage of wood decomposition (Ischnoderma benzoinum).

Lawrynowicz (1982) noted the absence of Fomes fomentarius and Piptoporus betulinus from the inner city of Łódź (Poland), in spite of the abundance of suitable hosts there.

We have already referred to the weak long-distance dispersal in wood-rotting fungi. An increase in the distance between possible niches may very soon lead to drastic decrease or disappearance of the populations of certain otherwise abundant species. Even slight human interference changes the competitive balance among the species, and many peripheralpattern polypores are the first to disappear. Conversely, large clumps of suitable hosts (e.g. dense willow and Corylus thickets of site type V) may support rich populations of rare polypores that are virtually absent from sparse scattered host stands. An example is
Daedaleopsis confragosa. This phenomenon and problem has been encountered elsewhere in Finland. Antrodia albobrunnea (Rom.) Ryv., Haploporus odorus (Somm.) Bond. \& Sing., Pycnoporellus fulgens and Spongiporus guttulatus are generally very rare, but when found are mostly seen to inhabit many trees within a small area, and may even be locally abundant. Changes in the ecology or size of such areas easily lead to losses of endangered species.

Peripheral polypores form a more heterogeneous group than the other two. They may be saprophytic species of fallen trunks and stumps, parasites that kill the trees, species with perennial fruit bodies, species with a strong preference for indigenous hosts, species preferring conifers, species causing brown-rot, small ephemeral species occurring on bushy hosts, or species favouring shady biotopes with a humid microclimate. The bulk of them is made up by the common and widely distributed basic polypores found in any ordinary forest in southern or central Finland. It appears that many of them are not very adaptive ecologically.

Indifferent. Few species showed clear distributional indifference, though the maps of many polypores implied such a pattern. Some typical examples are small ephemeral species with annual fruit bodies that are saprophytic (Trametes hirsuta), saproparasitic (T. pubescens), or more strongly parasitic (Bjerkandera adusta). It is mainly the parasitic habit that allows these species to persist in the inner city, especially if they can occupy scars of pruned-off branches (T.pubescens) or rot sapwood in extensive butt bark injuries and trunk wounds (B. adusta). These early colonists (Frankland 1981) come and go continuously, never remaining long in the same place (Figs. 47, 52).

Other indifferent polypores are perennial, saproparasitic species that are predominantly saprophytic in the outskirts and parasitic in the inner city. They may cause butt rot (Ganoderma lipsiense), decay the heartwood throughout the length of the trunk (Ochroporus igniarius), or be more restricted (Fomitiporia punctata). They are generally slightly hemerophilous in Finland, and ecologically among the most adaptive in the Finnish polypore flora: they have the longest host lists in both this and earlier studies (Niemelä \& Kotiranta 1982, 1986). Some seem to be genetically variable ( $G$. lipsiense, and in particular $O$. igniarius) and their park-dwelling populations differ pathologically and also morphologically from those of the forested areas (Figs. 48, 49, 51). These centric populations may originate at least partially from the south.

Inonotus obliquus is an exceptional species in this group. It is exclusively parasitic, a specialist as regards its hosts and sporulates only after the tree has died. However, a slightly hemerophilous habit in southern and central Finland connects it with the other members of the group (Fig. 50). 

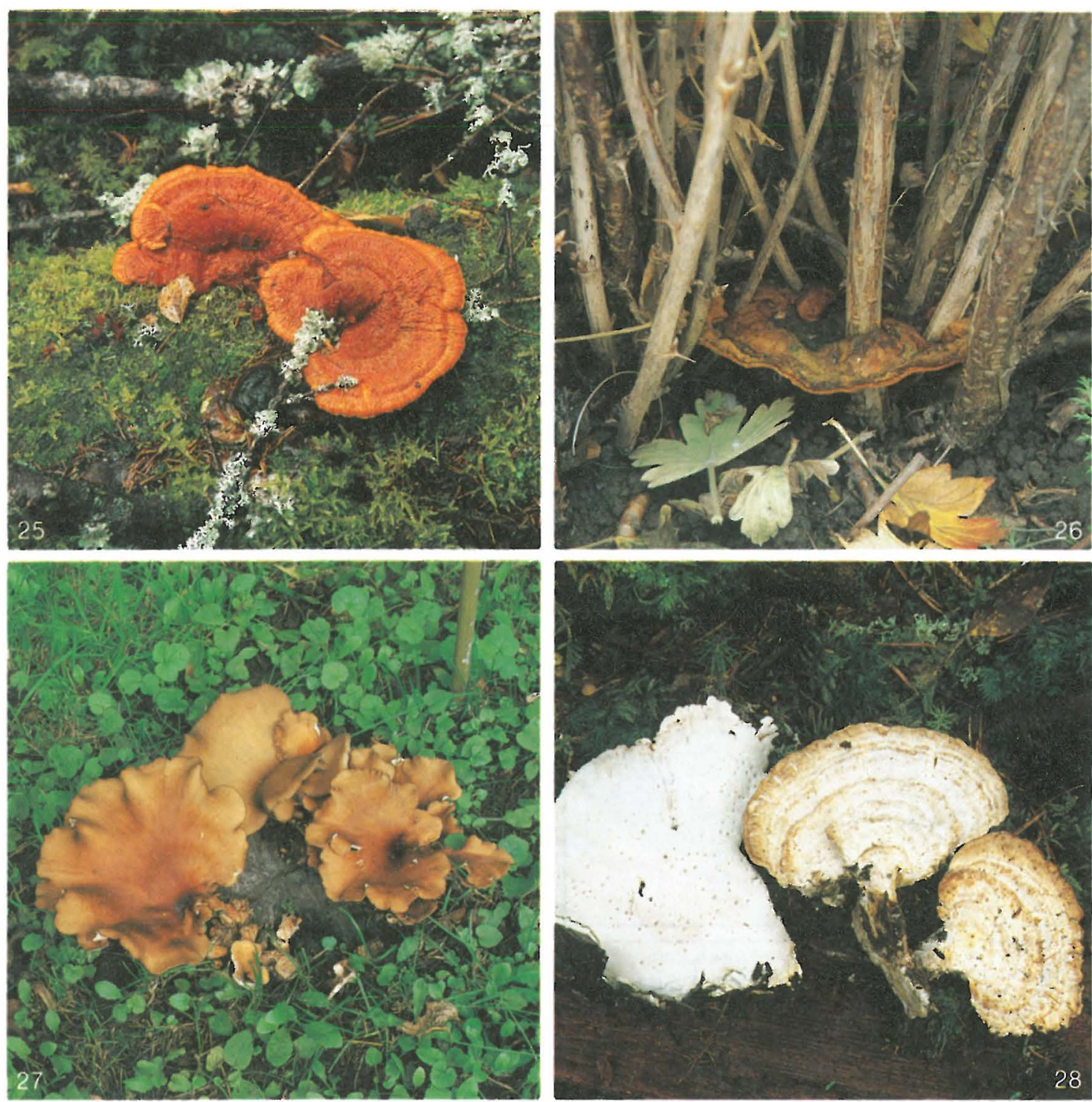

Figs. 25-28. Polypores with rare occurrences in Helsinki. - 25: Pycnoporellus fulgens on a fallen spruce. - 26: Phylloporla ribis at the base of Ribes uva-crispa. - 27: Polyporus badius in the University Botanical Garden. - 28: Spongiporus guttulatus, a rare saprophyte of broken spruce.

Notes. The main cause of the formation of different distributional types is the availability of suitable hosts. However, it became evident that many other factors are also responsible for the final pattern. We want to stress that our results and discussion describe the situation in Helsinki. Similar (though less distinct) distributional groups could surely be found in other towns of South Finland, and such patterns should be quite clear in the major cities of the other Nordic countries and the adjacent U.S.S.R. (Leningrad, Tallinn). Our results cannot be expected to be directly applicable in other regions, e.g. Central $\mathrm{Eu}-$ rope. But although the species will naturally differ, groups of 'centric', 'indifferent' or 'peripheral' polypores can probably be distinguished in any comparable urban/rural ecotone. 

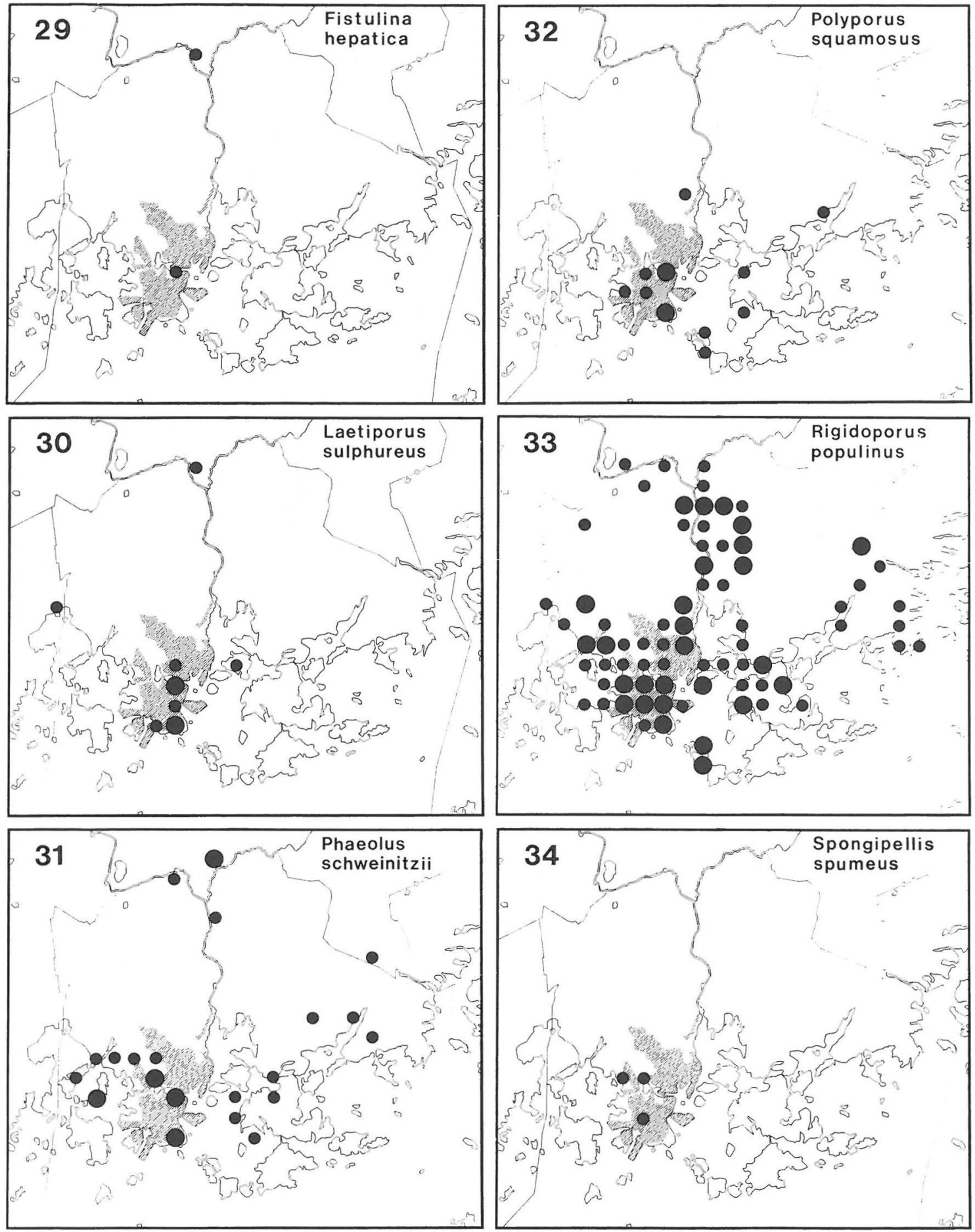

Figs. 29-34. Polypores with a centric distribution in Helsinki. Shaded areas mark the built-up inner city; small dots represent 1-2 observations and large dots 3 or more per square. - 29: Fistulina hepatica. - 30: Laetiporus sulphureus. - 31: Phaeolus schweinitzii. - 32: Polyporus squamosus. - 33: Rigidoporus populinus. - 34: Spongipellis spumeus. 

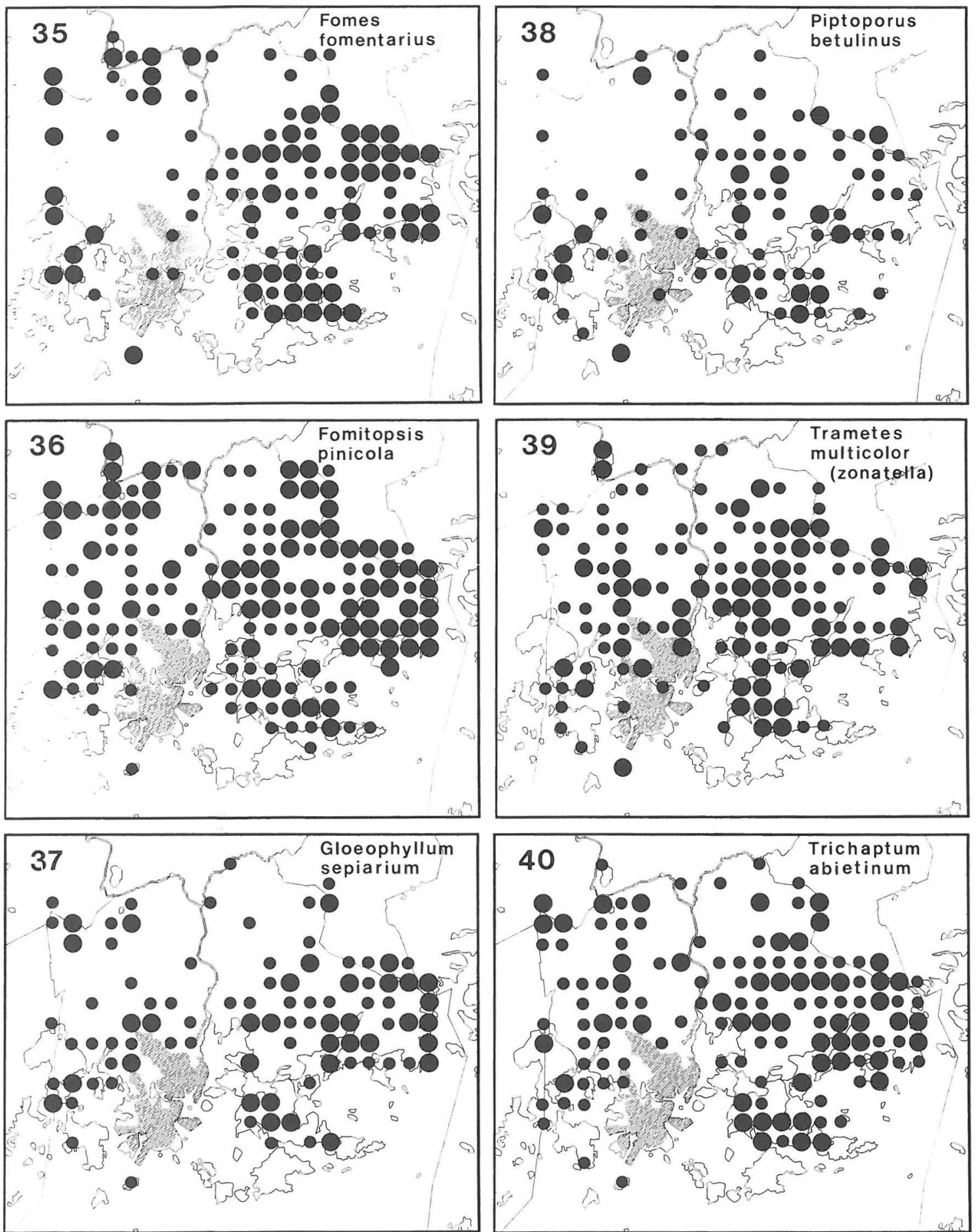

Figs. 35-40. Polypores with a peripheral distribution, very common. - 35: Fomes fomentarius, - 36: Fomitopsis pinicola. -37: Gloeophyllum sepiarium. - 38: Piptoporus betulinus. - 39: Trametes multicolor (T. zonatella). - 40: Trichaptum abietinum. 

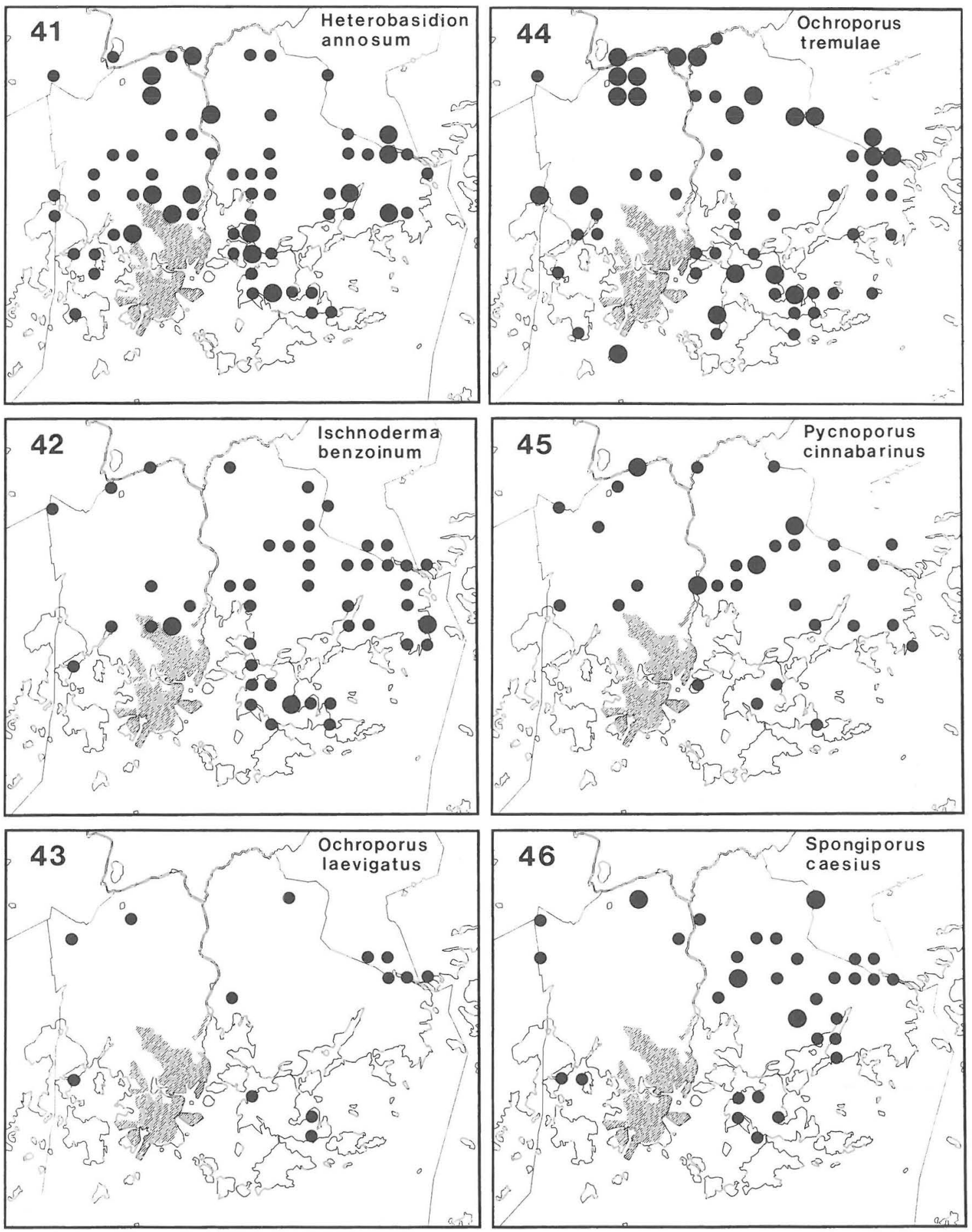

Figs. 41-46. Polypores with a peripheral distribution, common or scattered. - 41: Heterobasidion annosum. - 42: Ischnoderma benzoinum. - 43: Ochroporus laevigatus. - 44: Ochroporus tremulae. - 45: Pycnoporus cinnabarinus. - 46: Spongiporus caesius. 

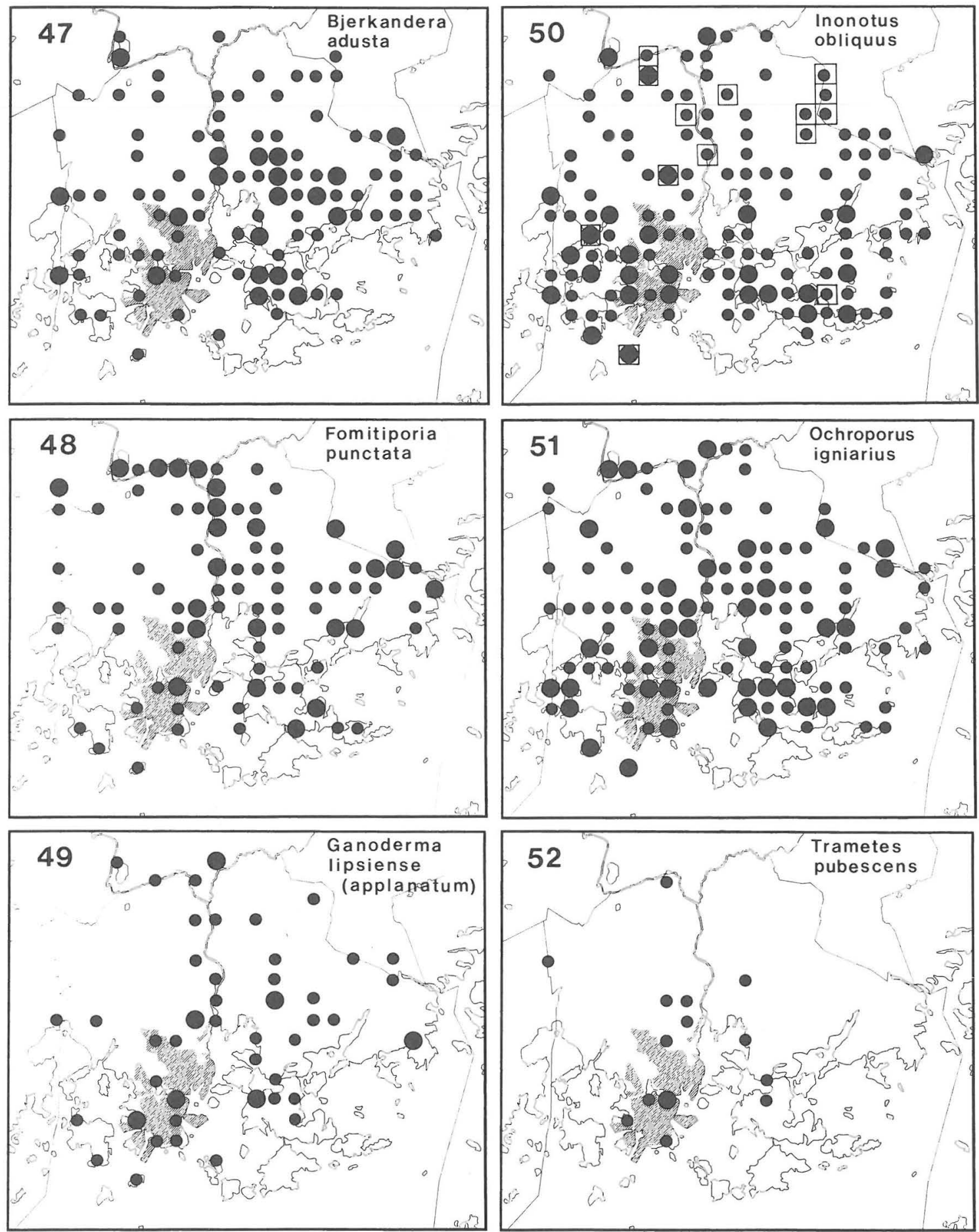

Figs. 47-52. Polypores with an indifferent distribution. - 47: Bjerkandera adusta. - 48: Fomitiporia punctata. - 49: Ganoderma lipsiense (G. applanatum). - 50: Inonotus obliquus (perfect stage indicated with squares). - 51. Ochroporus igniarius. - 52: Trametes pubescens. 

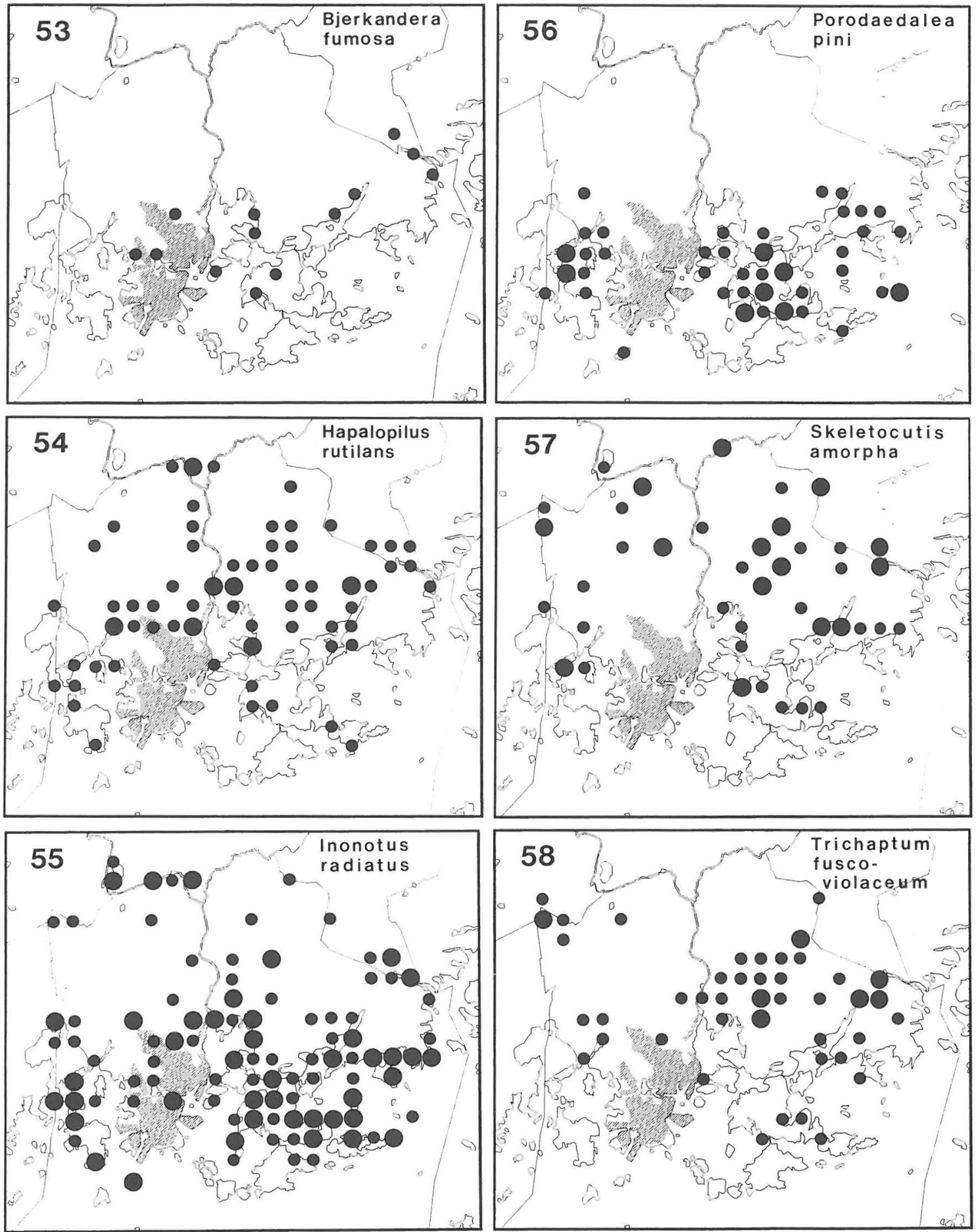

Figs. 53-58. Polypores with an exceptional distribution. - 53: Bjerkandera fumosa (old manor parks, etc.). - 54: Hapalopilus rutilans (rocky areas). - 55: Inonotus radiatus (predominantly coastal). - 56: Porodaedalea pini (strongly coastal). - 57: Skeletocutis amorpha (abundant, restricted occurrences). - 58: Trichaptum fuscoviolaceum (absent from coastal pine stands). 
This division has been noted among many other wood-rotting fungi. The hydnaceous Climacodon septentrionalis ( $\mathrm{Fr}$.) Karst. is a centric species (Koski-Kotiranta \& Niemelä 1986). The corticiaceous Stereum rugosum (Pers.: Fr.) Fr. is indifferent, and its saproparasitic habit and host relationships fit very well with the ecology of the indifferent polypores outlined above. Many tree-parasitizing Agaricales could surely also be classified in the same way.

\section{Decay in park trees:}

different types of damage

The terms 'parasite', 'saprophyte', 'saproparasite', etc. have been used here in the common sense (e.g. Rypáček 1966). We employ the term parasite for all those fungi that inhabit living tree trunks. We also use heartrot for both the decay of heartwood (e.g. Pinus, Quercus) and the decay of the inner column of trees which do not develop true heartwood (e.g. Acer, Betula). In this context, we found it difficult to adopt the fashionable division into saprotrophic, necrotrophic, etc. fungi (Frankland et al. 1982, Cooke \& Rayner 1984).

When classifying different types of decay in park trees in Hamburg, Seehann (1979) ranked Meripilus giganteus (Pers.: Fr.) Karst. as one of the most aggressive fungi, which kill the trees rapidly before extensive decay has developed. There are no certain records of M. giganteus in Finland, and in Helsinki we cannot place any polypore in the category of rapid killers.

The second group of Seehann (1979) comprises species which produce extensive decay along the trunk and branches; the rot expands slowly outwards. $\mathrm{He}$ included Ochroporus igniarius, which causes similar damage in the parks of Helsinki. Large individuals of Salix fragilis, for instance, resist the expanding decay for several decades, but finally the thicker branches collapse and the cambium dies around the groups of fruit bodies in the lower part of the stem, resulting in the death of the tree. In this final stage the whole trunk is rotten. Similar symptoms are caused by Rigidoporus populinus on Acer platanoides, Laetiporus sulphureus on Salix alba, and Inonotus obliquus on Betula pendula. These four fungi can be regarded as the most harmful pathogenic polypores in the old parks of Helsinki.

The third category (Seehann 1979) comprises species which cause a restricted and well-delimited column of decay in the inner part of the trunk, and which therefore do not greatly decrease the decorative value of the trees, or create hazards for the public. Representatives of this group in Helsinki are: Polyporus squamosus on Ulmus glabra and Fraxinus excelsior, Ganoderma lipsiense on various hardwoods, $P o-$ rodaedalea pini on Pinus sylvestris and Daedalea quercina on Quercus robur.

In his fourth group Seehann (1979) lists species attacking sapwood in and around bark wounds and injuries. He mentions Bjerkandera adusta and some species of Trametes (Coriolus) in the study from Hamburg, and they occur in Helsinki, as well. We could add Fomitiporia punctata and Porodaedalea conchata, both occurring on numerous ornamental trees and bushes. We failed to decide whether to place Spongipellis spumeus here, or in category 2 or 3; its infection seems to be closely connected with bark wounds, but the decay may chiefly extend to the inner wood.

We do not have any notable polypores that are restricted to tree branches (Seehann 1979: group 5). Of course, Polyporus squamosus and Ochroporus igniarius, among others, may extend to thicker branches after infecting the trunks.

The group of fungi causing root-rot could be added to the list of polypores attacking park trees. Phaeolus schweinitzii on Larix species is the best example in Helsinki; perhaps also Heterobasidion annosum in more forest-like environments (e.g. the park forests), though studies of cultures are needed to elucidate its true occurrence. The park-inhabiting variety of $\mathrm{Ga}$ noderma lipsiense causes butt-rot on deciduous trees; the fact that the fruit bodies emerge from stumps (also those cut very low, at ground level) gives the impression that it also decays the roots.

The polypores listed here are responsible for most of the decay encountered in the park trees in Helsinki.

\section{Decay in park trees:} causes and remedies

The main reason for fungal infections seems to be pruning, especially the removal of thick branches from adult trees. This practice is necessitated by the size of present-day trucks, buses and other vehicles, which are much higher than when the old street trees were planted. Different pruning techniques have been recommended: Shigo (1982) favours cutting a branch almost transverse to its axis, which makes a small wound, though it leaves an unappealing knot on the trunk. However, some observations (Hytönen 1985) have shown that scars callus over more rapidly if the bark collar at the base of a branch is cut. In Central Europe (especially Germany: Meyer 1982) even the biggest branches are usually removed along the trunk surface, which may look neat, but leaves a large and slowly healing scar. The best solution may lie between these extremes and depends on the tree species.

The probability of infection depends on the size of the scar, the regenerative capacity of the tree (e.g., time needed for complete healing) and its natural resistance to fungi. Trees whose branch and crown 
structure provides adequate vertical clearance have an advantage over the others, because no pruning into a standard from is then needed.

City arborists in Helsinki regard Betula pendula as the most troublesome park tree, because of its slowly healing bark and rapidly developing decay. Its maximum age in parks averages 60 years. Tilia $\times$ vulgaris is placed second in its susceptibility to decay, which is surprising in view of our results: fruit bodies were observed extremely rarely on Tilia, and no polypore species was found to have specialized on it. The vigorous growth of sound new wood layers may hinder fruit body formation on the trunk; it also makes the trees sturdy and safe in the parks, in spite of the rotten inner wood column. Acer platanoides is the third most susceptible to decay, and the risk of thick branches breaking off (mainly caused by Rigidoporus populinus decay in branch joints) must be taken into account. The most resistant trees are Ulmus glabra and Quercus robur, and the latter has been planted much more frequently in recent years. Unfortunately, Ulmus does not tolerate the poor soils and surfacing of the boulevards, and tends to die just on the verge of maturation. The Dutch elm disease does not cause trouble in Helsinki.

Resistance to fungi may vary considerably even between closely allied tree species. According to our results, Salix fragilis is chronically susceptible to infection by Ochroporus igniarius var. igniarius, while $S$. alba is highly resistant to the fungus (Fig. 16).

Trunk and butt injuries caused by automobiles and snow-removal devices are increasing rapidly. Various guards have been designed for newly planted trees along sidewalks (Figs. 59-61), but the mature - and most valuable - trees have little protection. Sidewalk trees also suffer root damage during construction work and excavation of electric and telephone wires, but the connection of such damage with decay could not be examined. Root-rot caused by Heterobasidion annosum and Phaeolus schweinitzii is not found in sidewalk trees.

Frost cracks on trees give easy entry to pathogenic fungi. Exposed trees in parks and roadsides should be especially susceptible to frost cracks, though the frost damage depends greatly on the species. Himelick (1976) listed 8 park-tree genera that are often affected in this respect in Illinois, U.S.A., among them Acer, Aesculus, Quercus, Salix, Tilia and Ulmus. In Helsinki, frost cracks are very common in Tilia and Betula, but are rarely found in other genera. Frost cracks do not cause much trouble in Helsinki (Hytönen, pers. comm.).

Urban environments involve other types of stress for trees besides mechanical injuries. The moisture status of the trees is unfavourable, especially along the freeways elevated on fill, and may be critical during hot summer days in the inner city, too. Construc- tion work may also raise the water table in some areas. Atmospheric contaminants have adverse effects on the growth of trees. A great problem is accumulation of salt in soils, as a result of the use of de-icing salts during winter (Dirr 1976). Streets that are heavily de-iced also give off salt spray, which accumulates directly on the trunk and branch bark. These factors increase tree mortality, but little attention has been paid to their indirect effects on city trees, e.g. to whether roadside pollution decreases the ability of trees to resist fungal attacks (Himelick 1976). The fact that Piptoporus betulinus appears abruptly on moribund or water-stressed birches (Cooke \& Rayner 1984) points to reduced resistance.

An observation from Helsinki may serve to illustrate the effects of salt stress. In 1979, brackish water was pumped from the sea to a pond in the Kaisaniemi park, the purpose being to raise the water table so that the pole foundations of the old buildings surrounding the park would not decay. As a result, the abundant Salix alba plantations bordering the pond (Fig. 5) started to suffer, and accumulation of sodium chloride was observed in the bark and new wood layers (Hytönen, pers.comm.). The pumping of salty water to the pond was stopped, and the trees started to recover. However, in 1979-1986, Laetiporus sulphureus erupted in many of these particular trees, weakening and killing them one after another.

The possibility of fungal infection increases with the life-span. Park trees are kept for much longer than is usual in forestry rotation, which in itself increases the probability of decay. It is a wonder than park trees survive the hostile urban conditions as well as they do.

Prevention is better than cure; indeed, once the tree has succumbed to decay, no cure is possible. Antifungal wood-dressing paints (see Mercer 1982) are often applied to the branch scars and bark injuries in the park and roadside trees; Shigo et al. (1979) and Shigo (1982) claim that this practice is of little help and in many cases has adverse effects. Mercer (1982) considers that such dressings are effective only if they form an airtight seal, blocking the oxygen input to the wood.

New brands of wood-dressing paints have been developed since the experiments of Shigo and have been tested on some common park trees in Helsinki (Hytönen 1985), with very encouraging results. The degree of new decay diminished significantly, and the callus growth rate improved by about $40 \%$. The reason why wood-dressing paint promotes the formation of callus is not known. The only drawback to the treatment is its limited durability: the wounds require repainting every second year. Application of latexbased Bayleton paint is now standard practice in Helsinki. In Stockholm, Sweden, on the other hand, park tree wounds and branch scars are left untreated. 

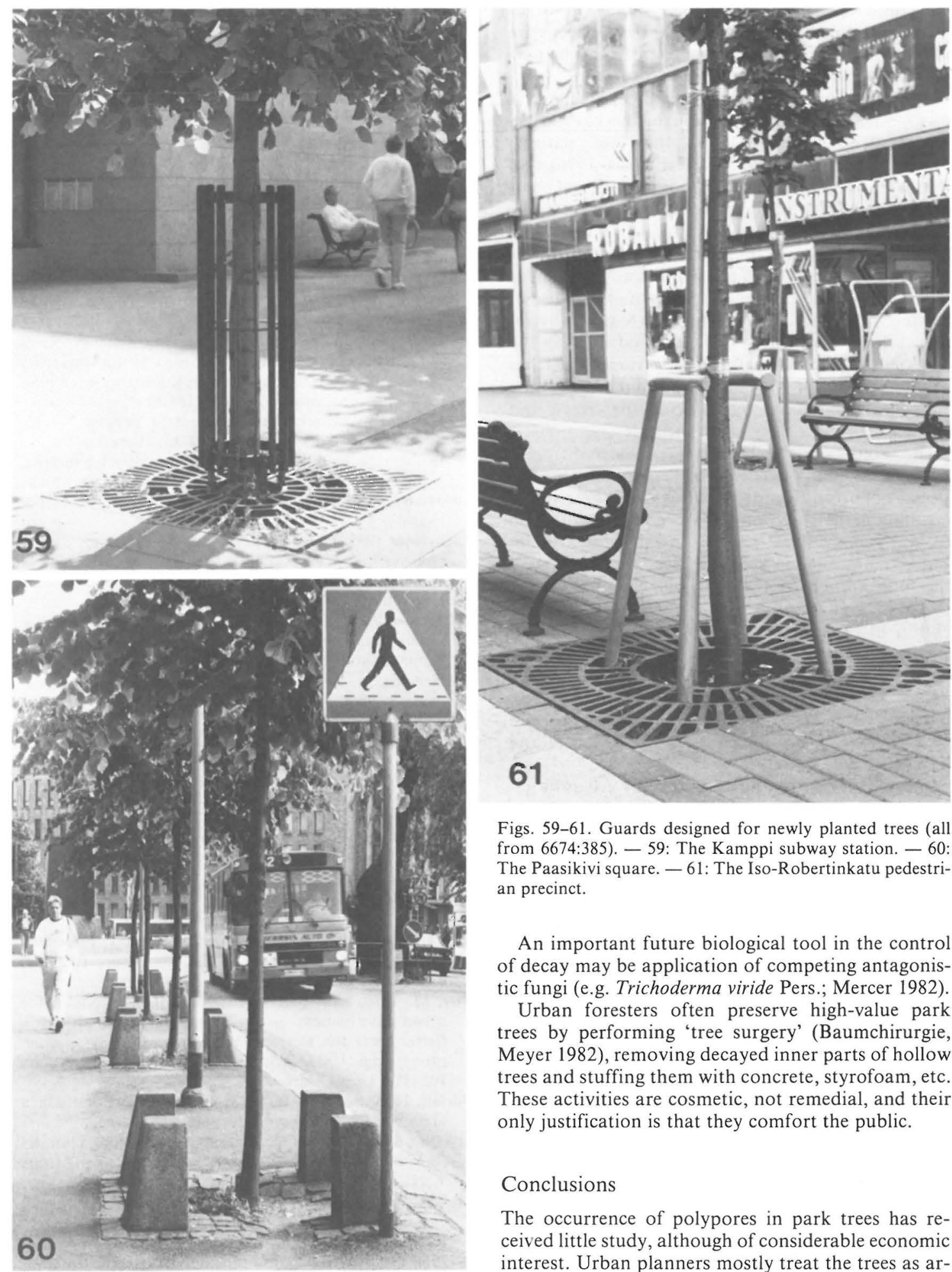

Figs. 59-61. Guards designed for newly planted trees (all from 6674:385). - 59: The Kamppi subway station. - 60: The Paasikivi square. - 61: The Iso-Robertinkatu pedestrian precinct.

An important future biological tool in the control of decay may be application of competing antagonistic fungi (e.g. Trichoderma viride Pers.; Mercer 1982).

Urban foresters often preserve high-value park trees by performing 'tree surgery' (Baumchirurgie, Meyer 1982), removing decayed inner parts of hollow trees and stuffing them with concrete, styrofoam, etc. These activities are cosmetic, not remedial, and their only justification is that they comfort the public.

\section{Conclusions}

The occurrence of polypores in park trees has received little study, although of considerable economic interest. Urban planners mostly treat the trees as ar- 
chitectural elements, rather than biological organisms, expecting them to thrive if their basic needs are fulfilled (illumination, watering, fertilizers). Their occasional premature death comes as a surprise.

On the other hand, trees are highly appreciated in towns, since they soften the harsh, mechanical environment (Santamour 1976), they are 'nature's air conditioners' (Heisler \& Herrington 1976) and they have a very direct influence on the thermal comfort of man. The purpose of woody vegetation in the city is different from that of forestry - it is cultivated primarily for aesthetic purposes, not wood production. Therefore decay in a tree trunk is no problem, as long as there is no danger of the death or collapse of the tree. In Helsinki, decayed trees are generally removed if less than $15 \%$ of sound wood is left in the butt transection. Sidewalk Tilia $\times$ vulgaris reaches this stage in about 70 years. Important trees can be kept even longer, e.g. by reducing the crown and removing the most risky big branches.

The subject also deserves to be considered from a mycological point of view. Urban environments offer special opportunities for the growth of some fungi, including many rare ones. These deserve protection like any other natural objects. In this study, for instance, many unique records have been presented. The following polypores, found in Helsinki, are regarded as endangered or in need of protection or attention in Finland (Anon. 1986a): Antrodiella onychoides, Daedalea quercina, Daedaleopsis confragosa, Fistulina hepatica, Gloeophyllum abietinum, Onnia tomentosa, Phylloporia ribis, Pycnoporellus fulgens, Spongipellis spumeus, Spongiporus guttulatus and Trametes suaveolens. Some species are colourful and showy - a delight to the eye.

Nature is destroyed in the course of urban development, but at the same time new biological patterns and species assemblages develop in the scanty green areas that remain among the built-up sections. These complexes are rare or even absent outside the urban areas, but as in the forests, fungi play an important role in wooded urban enclosures.

Acknowledgements. We are grateful to Mr Pentti Alanko, Lic.Phil., Prof. Leena Hämet-Ahti and Dr. Pertti Uotila (University of Helsinki), for providing us with information on the park trees of Helsinki. Mr Pekka Jyränkö, Head Gardener of the City of Helsinki, and Mr Teuvo Hytönen, Garden Technician (Helsinki), are thanked for several lengthy discussions concerning the parks, park trees, and management problems in the city; we are also grateful for the financial support which made the illustrations possible. Mr Krister Karttunen, Cand.Phil. (University of Helsinki), Prof. Hanns Kreisel (Ernst Moritz Arndt University, GDR) and Dr. Ingo Nuss (University of Regensburg, GFR) surveyed the literature on urban ecology and park-tree studies for us. Mr Heikki Kotiranta, Cand.Phil., Dr. Harri Nyberg and Mr Reima Saarenoksa (University of Helsinki) gave many field notes and new records for us to publish, and Dr.
Nils Hallenberg (University of Göteborg, Sweden) helped us to identify Schizopora radula. The curators of numerous herbaria are thanked for loans, and the personnel of the Helsinki city administration for repeated help in locating statistical and other data on the parks.

Mrs Anna A. Damström, M.A., revised the English.

\section{References}

Ainsworth, G. \& Sussman, A. 1968: The fungi, an advanced treatise 3 . The fungal population. -738 pp. New York \& London.

Alanko, P. 1981: Kaivopuiston puut ja pensaat. - In: Uotila, P., Sundman, M. \& Lindholm, T. (eds.), Kaivopuisto. 24 pp. Helsinki. [Also published in Dendrol. Seuran Tied. 12: 76-100, 1981.]

- 1983a: Kasvitieteellisen puutarhan ruostesienet. Rusts (Uredinales) in the Botanical Garden of the University of Helsinki. - In: Jalas, J. (ed.), Kasvitieteellisen puutarhan eliömaailmaa 1: 95-102. Helsinki.

- 1983b: Kaisaniemen puiston puut ja pensaat. - In: Lindholm, T. (ed.), Kaisaniemi: 9-15. Helsinki.

- 1983c: Helsingin yliopiston kasvitieteellinen puutarha. - In: Lindholm, T. (ed.), Kaisaniemi: 16-19. Helsinki.

Anonymous [1979]: Haltiavuoren luontopolku. - 17 pp. Helsinki.

Anonymous 1983: Pääkaupunkiseudun arvokkaimmat luonnonsuojelukohteet. Compiled by V. Hosiaisluoma. Pääkaupunkiseudun Julkaisusarja A 1983(5): 1-185. Helsinki.

Anonymous 1986a: Uhanalaisten eläinten ja kasvien suojelutoimikunnan mietintö 3. Suomen uhanalaiset kasvit. Ympäristöministeriö, komiteamietintö 1985(43). 431 pp. Helsinki.

Anonymous 1986b: Viikin puulajipuiston luontopolku. -32 unnumbered pp. Helsinki.

Benkert, D. 1977: Die Porlinge und Schichtpilze der Potsdamer Umgebung. - Gleditschia 5: 165-202.

Bernicchia, A. \& Furia, A. 1982: Antrodia onychoides (Egel.) Ryv. specie nuova per l'Italia 2. - Giorn. Bot. Ital. 116: 143-147.

Cooke, W. 1979: The ecology of fungi. - 274 pp. Boca Raton.

Cooke, R. \& Rayner, A. 1984: Ecology of saprotrophic fungi. - 415 pp. London \& New York.

David, A. 1980: Étude du genre Tyromyces sensu lato: Répartition dans les genres Leptoporus, Spongiporus et Tyromyces sensu stricto. - Bull. Soc. Linn. Lyon 49: 6-56.

Dirr, M. 1976: Salts and woody-plant interactions in the urban environment. - In: Santamour, F. et al. (eds.), Better trees for metropolitan landscapes. Symposium proceedings. USDA For. Serv. Gen. Techn. Rep. NE-22: 103-111. Upper Darby, PA.

Dörfelt, H. \& Sommer, B. 1973: Pilzfunde im Botanischen Garten Halle. - Mykol. Mitt.-blatt 17: 36-43.

Eriksson, J. \& Strid, Å. 1969: Studies in the Aphyllophorales (Basidiomycetes) of northern Finland. - Ann. Univ. Turku (A II) 40 (Rep. Kevo Subarctic Sta. 4): 112-158.

Erkkilä, R. 1984: Käävät Helsingin puistoissa ja metsissä. - Unpubl. Cand. Phil. thesis, Dept. of Botany, Univ. of Helsinki. 104 pp. Helsinki.

- 1986: Distribution maps of the polypores in Helsinki. - 
53 pp. Mimeo., Helsinki.

Esser, K. \& Hoffmann, P. 1977: Genetic basis for speciation in higher Basidiomycetes with special reference to the genus Polyporus. - In: Clémençon, H. (ed.), The species concept in Hymenomycetes: 189-201. Lehre.

Fiasson, J.-L. \& Niemelä, T. 1984: The Hymenochaetales: a revision of the European poroid taxa. - Karstenia 24: 14-28.

Frankland, J. 1981: Mechanisms in fungal successions. - In: Wicklow, D. \& Carroll, G. (eds.), Fungal community, its organization and role in the ecosystem: 403-426. New York \& Basel.

Frankland, J., Hedger, J. \& Swift, M. 1982: Decomposer basidiomycetes, their biology and ecology. $-355 \mathrm{pp}$. Cambridge.

Gerhard, E. 1978: Die höheren Pilze des Langen Luch (in Berlin). - 184 pp., 23 pl.pp. [Berlin].

- 1979: Die höheren Pilze des Langen Luch (in Berlin), Nachtrag. - Willdenowia 9: 261-282.

Gilbertson, R. \& Ryvarden, L. 1985: Some new combinations in the Polyporaceae. - Mycotaxon 22: 363-365.

Grey, G. \& Deneke, F. 1978: Urban forestry. - 279 pp. Stuttgart.

Grosse-Brauckmann, H. 1985: Holzbewohnende Aphyllophorales und Heterobasidiomyceten aus Südhessen. Z. Mykol. 51: 61-74.

Grosse-Brauckmann, H. \& Grosse-Brauckmann, G. 1983: Holzbewohnende Basidiomyceten eines Auenwaldgebietes am Rhein. - Z. Mykol, 49: 19-44.

Grosse-Brauckmann, H. \& Jahn, H. 1983: Antrodiella onychoides (Egeland) Niemelä. Erste Funde in Mitteleuropa. Unterschiede gegenüber Antrodiella semisupina (Berk. \& Curt.) Ryv. - Westfäl. Pilzbr. 10-11: 237-248.

Hallenberg, N. 1983: On the Schizopora paradoxa complex (Basidiomycetes). - Mycotaxon 18: 303-313.

Hämet-Ahti, L. et al. (eds.) 1984: Retkeilykasvio. - 544 pp. Helsinki.

Härkönen, M. 1983: Puutarhan limasienet. Myxomycetes in the Botanical Garden of the University of Helsinki. In: Jalas, J. (ed.), Kasvitieteellisen puutarhan eliömaailmaa 1: 103-110. Helsinki.

Heikinheimo, O. \& Raatikainen, M. 1971: Paikan ilmoittaminen Suomesta talletetuissa biologisissa aineistoissa. The recording of localities of biological finds in Finland. - Ann. Entomol. Fennici 37(1a): 1-27.

Heisler, G. \& Herrington, L. 1976: Selection of trees for modifying metropolitan climates. - In: Santamour, G. et al. (eds.), Better trees for metropolitan landscapes. Symposium proceedings. USDA For. Serv. Gen. Techn. Rep. NE-22: 31-37. Upper Darby, PA.

Himelick, E. 1976: Disease stresses of urban trees. - In: Santamour, G. et al. (eds.), Better trees for metropolitan landscapes. Symposium proceedings. USDA For. Serv. Gen. Techn. Rep. NE-22: 113-125. Upper Darby, PA.

Hytönen, T. 1985: Puiden haavat ja niiden hoito. - Puutarhauutiset 1985(19): 512-513, 524

Jalas, J. (ed.) 1983: Helsingin yliopiston kasvitieteellinen puutarha 1833-1983. - Kasvitieteellisen puutarhan eliömaailmaa 1. 136 pp. Helsinki.

Karlvall, F. 1963: Storsvampar i Göteborgs Botaniska Trädgård, dess naturpark och arboretum. - Acta Hort. Gotoburg. 26: 19-62.

Korhonen, M. 1983: Kasvitieteellisen puutarhan suursienistä.
Macrofungi in the Botanical Garden of the University of Helsinki. - In: Jalas, J. (ed.), Kasvitieteellisen puutarhan eliömaailmaa 1: 75-82. Helsinki.

Koski-Kotiranta, S. \& Niemelä, T. 1986: Wood-inhabiting fungi of the Auriscalpiaceae, Hericiaceae and Climacodontaceae in northwestern Europe. - Karstenia 26 (in press).

Kotiranta, H. 1980: Neljän etelähämäläisen alueen kääpälajisto. - Unpubl. Cand.Phil. thesis, Dept. of Botany, Univ. of Helsinki. 83 pp. Helsinki.

- 1985: Physisporinus rivulosus, an interesting polypore species. - Karstenia 25: 66-69.

Kotiranta, H. \& Niemelä, T. 1981: Composition of the polypore communities of four forest areas in southern Central Finland. - Karstenia 21: 31-48.

Kreisel, H. 1967: Die Pflanzenbestande des Botanischen Gartens der Ernst Moritz Arndt Universität, Greifswald 3. Die Grosspilze des Greifswalder Botanischen Gartens. - Wiss. Z. Ernst Moritz Arndt Univ. Greifswald 16: 229-329.

Kuusi, T., Laaksovirta, K., Liukkonen-Lilja, H., Lodenius, M. \& Piepponen, S. 1981: Lead, cadmium, and mercury contents of fungi in the Helsinki area and in unpolluted control areas. - Z. Lebensm. Unters. Forsch. 173: 261267.

Laaksovirta, K. \& Alakuijala, P. 1978: Lead, cadmium and zinc contents of fungi in the parks of Helsinki. - Ann. Bot. Fennici 15: 253-257.

Laine, L. 1967: Notes on the polypores (Polyporaceae) of Ahvenanmaa. - Karstenia 6-7: 14-20.

- 1976: The occurrence of Heterobasidion annosum (Fr.) Bref. in woody plants in Finland. - Comm. Inst. For. Fenniae 90(3): 1-53.

Lawrynowicz, M. 1982: Macrofungal flora of Łódź. - In: Bornkamm, R., Lee, J. \& Seaward, M. (eds.), Urban ecology. 2nd Eur. Ecol. Symp. Berlin 1980: 41-47. Oxford.

Leskinen, P. 1976: Männyllä kasvavat epifyyttijäkälät ilman saastuneisuuden ilmaisijoina Länsi-Helsingissä ja ItäEspoossa. - Unpubl. Cand. Phil. thesis, Dept. of Botany, Univ. of Helsinki. 126 pp. Helsinki.

Lodenius, M., Kuusi, T., Laaksovirta, K., Liukkonen-Lilja, H. \& Piepponen, S. 1981: Sienten kadmium-, elohopea- ja lyijypitoisuuksista Suomessa. - Ympäristö ja Terveys 1981(6): 399-408.

Malenç on, G. 1966: Polyporus peckianus Cooke en Europe? - Bull. Soc. Natural. Oyonnax 16-18: 35-39.

Mercer, P. 1982: Basidiomycete decay of standing trees. In: Frankland, J. et al. (eds.), Decomposer basidiomycetes, their biology and ecology: 143-160. Cambridge.

Meyer, F. (ed.) 1982: Bäume in der Stadt. - 380 pp. Stuttgart.

Niemelä, T. 1970: New data on Albatrellus syringae (Parmasto) Pouzar and A. peckianus (Cooke) Niemelä, n.comb. - Ann. Bot. Fennici 7: 52-57.

- 1972: On Fennoscandian polypores 2. Phellinus laevigatus (Fr.) Bourd. \& Galz. and P. lundellii Niemelä, n.sp. - Ann. Bot. Fennici 9: 41-59.

- 1975: On Fennoscandian polypores 4. Phellinus igniarius, P. nigricans and P. populicola, n.sp. - Ann. Bot. Fennici 12: 93-122.

- 1977: On Fennoscandian polypores 5. Phellinus pomaceus. - Karstenia 17: 77-86. 
- 1978a: On Fennoscandian polypores 6. Antrodia plicata, n.sp. - Karstenia 18: 43-48.

- 1978b: The occurrence of some rare pore fungi in Finland. - Ann. Bot. Fennici 15: 1-6.

- 1980: On Fennoscandian polypores 7. The genus Pycnoporellus. - Karstenia 20: 1-15.

- 1981: Polypores rare in or new to Finland. - Karstenia 21: $15-20$

- 1982: Polypore survey of Finland 1. Introduction. Karstenia 22: 21-26.

- 1985a: On Fennoscandian polypores 9. Gelatoporia n.gen. and Tyromyces canadensis, plus notes on Skeletocutis and Antrodia. - Karstenia 25: 21-40.

- 1985b: Mycoflora of Poste-de-la-Baleine, northern Québec. Polypores and the Hymenochaetales. - Naturaliste canadien 112: 445-472.

- 1986: Suomen kääpien määritysopas. - Helsingin Yliop. Kasvit. Lait. Monist. 98: 1-97. Helsinki.

Niemelä, T. \& Erkkilä, R. 1983: Käävät Helsingin yliopiston kasvitieteellisessä puutarhassa. Polypores in the Botanical Garden of the University of Helsinki. - In: Jalas, J. (ed.), Kasvitieteellisen puutarhan eliömaailmaa 1: 8393. Helsinki.

Niemelä, T. \& Kotiranta, H. 1982: Polypore survey of Finland 2. The genus Phellinus. - Karstenia 22: 27-42.

- 1983: Polypore survey of Finland 3. The genera Coltricia, Inonotopsis, Inonotus and Onnia. - Karstenia 23: 15-25.

- 1986: Polypore survey of Finland 4. Phaeolus, Fistulina, Ganoderma and Ischnoderma. - Karstenia 26 (in press).

Norokorpi, Y. 1979: Old Norway spruce stands, amount of decay and decay-causing microbes in northern Finland. - Comm. Inst. Forest. Fenniae 97(6): 1-77.

Nuss, I. 1970: Die Porlinge der Pfaueninsel und ihre Probleme, dargestellt an ausgewählten Beispielen. - Unpubl. State Examin. thesis, Pädagog. Hochschule Berlin. 131 pp. Berlin.

Nyberg, T. 1960: Eräiden kaarnajäkälien esiintymisestä Helsingin itäosissa. - Unpubl. Cand. Phil. thesis, Dept. of Botany, Univ. of Helsinki. 114 pp. Helsinki.

Palmén, A. 1985: Helsingin yliopiston kasvitieteellisen puutarhan puuvartiset kasvit. The woody plants of the Botanical Garden, University of Helsinki. - Ulmus 1: 1-60.

Pouzar, Z. 1966: Studies in the taxonomy of the polypores 2. - Folia Geobot. Phytotax. Bohemoslovaca 1: 356-375.

- 1967: Studies in the taxonomy of the polypores 3. Česká Mykol. 21: 205-212.

- 1974: An observation on Albatrellus subrubescens (Polyporaceae). - Folia Geobot. Phytotax. Bohemoslovaca 9: 87-94.

- 1984: Notes on four European polypores. - Česká Mykol. 38: 203-204.

Ryman, S. \& Holmåsen, I. 1984: Svampar, en fälthandbok $-718 \mathrm{pp}$. Stockholm.

Rypáček, V. 1966: Biologie holzzerstörender Pilze. - 211 pp. Jena.

Ryvarden, L. 1976: The Polyporaceae of North Europe 1. Albatrellus to Incrustoporia. - $214 \mathrm{pp}$. Oslo.

- 1978: The Polyporaceae of North Europe 2. Inonotus to Tyromyces. - pp. 219-507. Oslo.

Ryvarden, L. \& Johansen, I. 1980: A preliminary polypore flora of East Africa. - 636 pp. Oslo.
Santamour, F., Gerhold, H. \& Little, S. (eds.) 1976: Better trees for metropolitan landscapes. Symposium proceedings. - USDA For. Serv. Gen. Techn. Rep. NE-22: 1-256. Upper Darby, PA

Seaward, M. 1979: Lower plants and the urban landscape. - Urban Ecol. 4: 217-225.

Seehann, G. 1979: Holzzerstörende Pilze an Strassen- und Parkbäumen in Hamburg. - Mitt. Deutsch. Dendrol. Ges. 71: 193-221.

Selik, M. 1968: Holzzerstörende Pilze auf in- und ausländischen Holzpflanzen im Botanischen Garten Darmstadt und seiner nächsten Umgebung. - Mitt. Deutsch. Dendrol. Ges. 63: 86-90.

Selik, M. \& Aksu, S. 1967: Istanbulun park ve korularindaki yerli veyabanci ağaç türlerine ariz olan odun tahrip eden mantarlar. - Istanbul Üniv. Orman Fak. Derg. A 17: 90-101.

Shigo, A. 1982: A pictorial primer for proper pruning. Forest Notes, Soc. Protect. N. Hampshire Forest: 1-4.

Shigo, A., McGinnes, E., Funk, D. \& Rogers, N. 1979: Internal defects associated with pruned and nonpruned branch stubs in black walnut. - USDA For. Serv. Res. Pap. NE-440: 1-27.

Sukopp, H. \& Werner, P. 1983: Urban environments and vegetation. - In: Holzner, W., Werger, M. \& Ikusima, I. (eds.), Man's impact on vegetation: 247-340. The Hague.

Szober, J. 1965: Grzyby wyżse Ogrodu Botanicznego Uniwersytetu Warszawskiego. - 19 pp. Warszawa.

Thesleff, A. 1920: Studier öfver basidsvampfloran i sydöstra Finland. - Bidr. Känned. Finlands Nat. Folk 79(1): $1-140$.

Toikka, A. 1975: Männyn rungolla kasvavien jäkälien esiintymisestä ja ilman saasteista Itä-Helsingissä. - Unpubl. Cand. Phil. thesis, Dept. of Botany, Univ. of Helsinki. $55 \mathrm{pp}$. Helsinki.

Tutin, T. et al. (eds.) 1964: Flora Europaea 1. - 464 pp. Cambridge.

Uotila, P., Sundman, M. \& Lindholm, T. (eds.) 1981: Kaivopuisto. -24 pp. Helsinki. [Also published in Dendrol. Seuran Tied. 12: 76-100, 1981.]

Vaarna, V. 1934: Helsingin kaupungin puiden ja pensaiden jäkäläkasvisto. Über die epiphytische Flechtenflora der Stadt Helsinki. - Ann. Bot. Soc. Vanamo 5(6): 1-32.

Varis, M. 1959: Eräiden puunrunkojäkälien esiintymisestä Munkkiniemessä. - Unpubl. Cand. Phil. thesis, Dept. of Botany, Univ. of Helsinki. 91 pp. Helsinki.

Vitikainen, O. 1983: Kasvitieteellisen puutarhan jäkälistä Lichens in the Botanical Garden. - In: Jalas, J. (ed.), Kasvitieteellisen puutarhan eliömaailmaa 1: 69-74. Helsinki.

Wicklow, D. \& Carroll, G. (eds.) 1981: Fungal community, its organization and role in the ecosystem. -855 pp. New York \& Basel.

Wolkinger, F. 1973: Holzzerstörende Basidiomyceten auf Aesculus hippocastanum und Sophora japonica im Stadtgebiet von Graz. - Mitt. Naturwiss. Ver. Steiermark 103: 205-220.

Zion, R. 1968: Trees for architecture and the landscape. 284 pp. New York, Amsterdam \& London.

Accepted for publication

on 25 April 1986 